Article

\title{
Economicism and Nihilism in the Eclipse of Humanism
}

\section{Pedro Talavera}

Department of Philosophy of Law, Faculty of Law, University of Valencia, 46071 Valencia, Spain; E-Mail: ptalaver@uv.es; Tel.: +34-963-828129

Received: 28 April 2014; in revised form: 1 August 2014 / Accepted: 4 August 2014 /

Published: 11 August 2014

\begin{abstract}
This article is based on the conviction that the major problems nowadays are not technical, but ethical, and are incumbent on homo qua homo. The origin of these problems is the advancement of economicism as a supreme interpretation of human and social reality, which means the primacy of the "market" and considering human beings in terms of what they have rather than what they are. Economicism emerges in "modernity" and assumes that everything that does not have market value is either devaluated or rejected. In consequence, the human being has been devaluated and has turned into a simple object of the market. "Postmodernity" mixes economicism and techno-scientificism (chrematistics and instrumental rationality) with nihilism (absence of values), giving way to a technological and decadent capitalism that has erased "humanism" and the very idea of the human being. Thus, we are in urgent need of a humanist recovery of the "human" based on a rehabilitation of ontology.
\end{abstract}

Keywords: humanism; economicism; modernity; postmodernity

\section{Introduction}

The thesis I shall attempt to defend sets out that the abandonment of the humanities is directly linked to the eclipse of humanism, which began with the economicist paradigm of modernity and was consummated with postmodern decadent thinking, which has largely adopted an anti-humanist and nihilist direction, sustaining the futility of the very idea of being human. Foucault puts this in terms that could not be clearer: "The discoveries of Levi-Strauss, Lacan, Dumezil not only erase the traditional view of man, but also, in my view, tend to render the very idea of man useless for research and thinking. The most burdensome inheritance which in turn has been passed down to us from the 19th century — and which it is now time to rid ourselves of—is humanism” [1]. 
Nevertheless a peculiar phenomenon has come about: the economicist reductionism of modernity has given rise to postmodern anti-humanism; but the nihilist nature of postmodernity, far from overcoming the enlightenment paradigm, has contributed to augmenting techno-scientific development and the omnipotence of the market, reducing human beings themselves to an object that can be technically manipulated and economically quantified.

The historical epoch, which is known almost unanimously as "modernity", came into being near the middle of the fifteenth century under the sign of the primacy of the "market". Economic modernization contemplated the individual as a being who exchanged commodities, was solely concerned with his/her own wealth and stressed the visual, the quantitative and the disjunctive. Its motto was perfectly portrayed by the Frenchman, Guizot, during the reign of Louis Philippe of Orleans: "Enrichissez-vous!" The market became the only social institution that had to be vigorously defended.

However, economic modernization maintained a degree of autonomy from the cultural sphere because of its different epistemological and anthropological foundations and by way of its distinct organization. In effect, cultural modernization, which came about at the end of the eighteenth century, displayed a clear sense of hostility towards modernity: it defended the supremacy of secondary qualities and subconscious impulses over the predominance of geometric rationality. Theophile Gauthier's motto of l'art pour l'art was directly aimed at Guizot's slogan, as was Oscar Wilde's quip in his play Lady Windermere's Fan: "A man who knows the price of everything and the value of nothing.”

This hostility between economic modernization and cultural modernization became evident in the nineteenth century with the simultaneity of the defense of progress carried out by Spencer (the salient advocate of homo oeconomicus) and the spread of decadentism propagated by Baudelaire and Verlaine. However, the autonomy of these social spheres was slowly disappearing in so far as the economic world increasingly extended its power. At this moment, politics had abandoned all hopes of holding sway over the mercantile sphere, and it mimetically copied all of its procedures to the point that what was most important was the trademark and not the ideology. Culture and art, in turn, had become yet another element of consumption, something which is fragmentary and pleasant to juxtapose alongside that which is analytical and boring; aspects which are both characteristic of the age of production.

The advancement of economicism as a supreme interpretation of human and social reality produces hand-in-hand, on the plane of factual reality, the end of humanism and the success of post-structuralism and the poignantly called "pensiero debole" (weak thinking), which is none other than simple nihilism, the abandonment of rationality, and indeed of the very idea of the human being.

The most well-known advocate of "weak thinking”, Gianni Vattimo, states that our culture has adopted Nietzsche's nihilist conception, which means accepting the death of God and, with it, levelling the foundations of supreme values [2]. The essence of this "nihilism" consists of finally reducing all "use value" to "exchange value", and in the final analysis, human beings themselves are reduced to and identified as "exchange value". In this way, all values, freed from their foundations, become equivalent and interchangeable, and all reality becomes available ([2], p. 28). Herein, we have the peculiar convergence of economicism and nihilism, which will be analyzed later on. When everything is reduced to "exchange value", all reality takes on the nature of money; in other words, it can be exchanged indistinctly for any other thing. The apotheosis of "exchange value" extended to the whole of life includes human beings themselves, whose singularity (humanity) is dissolved to become something that is available and interchangeable, radically dispossessed of any hope of absolute value 
that supposedly granted them dignity. In short, nihilism ends up generating the merchandization of what is human by reducing it to a mere "exchange value". Consequently, the absolute hegemony of economicism, which has been imposed on society as the ultima ratio for politics, culture, the arts and the economy itself, does not originate solely from a spillover of the thirst for wealth and well-being, but rather from the loss of what is human as an absolute criterion of reference; it follows that attempts to submit the market and finances to a supposed "business ethics" fail time and time again. Overcoming economicism (the globalization of "exchange value”) inescapably requires overcoming nihilism, something which can only be done from the perspective of rehabilitating humanism.

With this in mind, this article analyzes the causes through which economicism has ended up becoming the fundamental exponent of modernity, then the manner in which postmodernity has adopted a nihilist drift and converged with economicism. Finally, I shall draw attention to a series of proposals that could form the basis for a "new humanism" capable of overcoming the economicist and nihilist drift and in which thinking and action would once again revolve around the "human/non-human" axis. In other words, the possibility to state in intellectual terms what is "good" for man as a counter argument to that which dehumanizes him drains him of his very being and reifies him.

\section{The Epistemological Revolution of Modernity}

From the very appearance of the term, "modernity" has been intimately linked to the exigency of “exactness”, of rigorous measurement [3]. This exigency has accompanied modernity throughout the centuries, thereby constituting the key element in its epistemological horizon. Indeed, the expression "modern" appeared for the first time (as Panofsky has stressed [4]) in the work of the great painter and art historian Giorgio Vasari (1511-1574) to designate the new way of painting paradigmatically as exemplified by Leon Battista Alberti (1404-1472) and Leonardo da Vinci (1452-1519) and which was characterized by its scientificity as opposed to the maniera antica of the classical painters or the maniera vecchia of the Byzantine artists.

Modernity came about in the Florence of the Medicis with the discovery of perspective by Brunelleschi, around 1420, of what he called costruzione legittima. Modernity appeared when the exigency of exactness present in the world of art was immediately copied in the scientific world, and it would subsequently be offered as the paradigm of all forms of knowledge. The "geometrization" (Euclidization) of art, which was introduced with perspective, would have profound consequences in the realm of general thought: it increasingly attempted to undervalue the oral in favor of the visual, the qualitative in favor of the quantitative or the analogical in favor of the disjunctive. To each of these processes there corresponds a salient figure: Leonardo da Vinci, Galileo and Descartes, respectively. I shall come back to this point, but I would first like to analyze what perspective implies, not so much for the history of art, but rather for the history of thought and vis-à-vis the conception of the world.

As Panofsky wrote in his book on perspective and in his book on the Renaissance, the dimension of perspective implies the belief in space, which is at the same time infinite and homogeneous. As he states: "Infinity is implicit in the fact that any set of parallel lines independently of their place and direction, converge onto a single point of escape” [5]. This was a new concept that had been introduced by Nicolas de Cusa and which was later developed by Descartes. 
The requirement of perspective (or put another way, the requirement of exactness) tended to devalue the qualitative dimension of objects, favoring the exclusive consideration of distance over their symbolic value. As Lewis Mumford was very sharp to grasp in his excellent book, Technics and Civilization: "The space of the hierarchy of values was replaced by the system of magnitudes [...]. Dimension no longer means divine or human importance but rather distance” [6]. This depreciation of the symbolic and the qualitative explains how the rump of a horse can appear in the forefront in Velázquez's painting The Rendition of Breda, something that was unthinkable in the pre-modern world.

Linked to this depreciation of the spatially qualitative is the reduction of the temporal sphere to the instantaneous moment due to the coincidence between exactness and instantaneity. As Ortega y Gasset points out, "Velázquez was determined to despotically set the point of vision. His entire painting was born out of a sole act of vision and all things had to strive in order to be able to arrive, as much as they possibly could, close to the visual line" [7]. This instantaneousness is the result of the radical break between the subject and the object, which also produced the loss of direct contact with things. This devaluation of the object is equally evident in Velázquez's work, as was pointed out in the book Velázquez y la Modernidad [8], constructed along the lines of Ortega's intuition mentioned above.

This unique perspective was based on the Euclidean reduction of geometry, the foundation of Western modernity. Therefore, it is not surprising that multiple perspectives should have returned to painting with the appearance of the new non-Euclidean geometries at the end of the nineteenth century [9]. However, now, it was a matter of continuing to expound on the consequences of the requirement of exactness within modern thought. This entailed, first of all, the shift away from the oral in favor of the visual.

This shift found a privileged place within the thinking of Leonardo da Vinci (1452-1519), the most brilliant artist of the different dimensions of design: painting, sculpture and architecture. In Aphorism 326, he writes, "The eye is the most noble of all the senses", since it is the sense that grasps objects with the greatest exactitude, whereas the sense of hearing is very inferior given its greater imprecision. Leonardo enters into the old debate introduced by Simonides of Ceos and Horatio on the hierarchy between poetry and painting, and he insistently stresses the superiority of the latter over the former, because only painting is science. Poetry is as fleeting as the auditory sensations, whereas visual sensations, according to him, are not fleeting [10].

As Kristeller [11] points out, this hegemony of the design arts, which would be unified by the very inventor of the word "modern", Vasari, is responsible for the disenchantment of the world, which has been accompanying modernity since its origins (supposing the latter is capable of being comprehended in its deepest origin) and which only appeared in its decline (when this radical penetration was missing). Indeed, the sacred in its unveiling is fundamentally united to the sense of hearing, since God can never be seen, whereas He can be heard. The rationalization form of knowledge leads to the profanation of reality: everything can be seen and therefore there is nothing sacred, as Max Weber so rightly pointed out in his Wissenschaft als Beruf: "Everything can be dominated by means of calculus and foresight” [12].

A further step in this modernizing process can be appreciated in the work of Galileo (1564-1642), for whom there is a shift from the qualitative to the quantitative, which accelerates the homogenization of reality. As he points out in his book, Il saggiatore [13], it is necessary to establish a radical separation between objective realities, which are susceptible to being known with exactness, such as 
numbers, figures, magnitudes, positions and motion, and what can only be known subjectively and approximately, such as sounds, tastes and smells. Maintaining Leonardo's thesis, Galileo stresses that the senses of hearing, touch and taste cannot provide rigorous knowledge, but rather only confused and ambiguous knowledge, which is not worthy of being considered as scientific in nature.

In his excellent and short article "From the world of the "more or less" to the horizon of exactitude" [14], Alexander Koyré called attention to the important role that technical discoveries played in this process, such as the appearance of mechanical clocks, which enabled the exact measurement of time and the appearance of the telescope, in addition to the growing use of Arabic numbers and algebra, as compared to the impossibility of carrying out exact calculations with Roman numbers, given their complexity.

This entire process of modernization culminated in the work of the French philosopher René Descartes (1596-1650), who systematized and made explicit all previous developments. His “clear and distinct idea" is nothing else, but the dimension of exactness, which was being sought ever since the Florence of the Medicis. In Descartes emerges the notion of subjectum, with his aim towards certainty and the will of dominion, but closely linked to this, there is internal breakage and laceration. Indeed, the requirement of exactness leads to the sole acceptation of univocal concepts and to the elimination of analogous concepts in such a manner that the very subject appears to be radically split in two: as res extensa subjected to space and geometry and as res cogitans, or self-conscience, placed outside of space and time. "From that I knew that I was a substance the whole essence or nature of which is to think, and that for its existence there is no need of any place, nor does it depend on any material thing; so that this 'me,' that is to say, the soul by which I am what I am, is entirely distinct from body, and is even more easy to know than is the latter; and even if the body were not, the soul would not cease to be what it is" [15].

The most immediate and intimate reality, the psychosomatic unity of the human person, is an insuperable aporia in Descartes' work, starting from disjunctive and exact thought, which denies analogy. Descartes, in effect, felt obliged to solve this aporia, either by resorting to the supernatural explanation according to which body and soul would be like two clocks simultaneously handled by God or else in a more contradictory fashion according to the remainder of his philosophy by suggesting (in his letter of 28 June 1643, to Princess Elisabeth de Bohéme ([15] t. III, p. 43)) that time is better spent talking and resting, since thinking would only be capable of making one aware of the opposition between body and soul, but not of their relationship.

Throughout the modern period, univocal and exact thought as axes of thinking generated a number of unresolvable dilemmas as regards the individual and society. Indeed, the demand for identity and rejection of analogy and complementarity would end up declaring certain essential realities as incompatible once considered from a disjunctive perspective. From this disjunctive thinking, it was affirmed both the negation of identity of the individual in opposition to God (nominalism, Luther) and the negation of God in opposition to human reality (Marx, Nietzsche and advocates of atheism). Furthermore, other false disjunctives were raised: between the individual and society, opening the way to radicalism in individualistic and collectivist doctrines; between obligation and happiness, the sources of puritanism and hedonism, respectively; and various others [16]. This dislocation of the world resulting from thinking in terms of identity-opposition and not in terms of difference-complementariness is precisely what the obsolescence of modernity reveals on the epistemological plane. 
At this point, I would like to show that the main consequence of the modern view of the world, based on the exclusiveness of the exact and on the negation of analogy is "economicism". Everything that does not have a market value (exchange value) lacks value. This premise, however, generates a paradoxical consequence: it is precisely what is human, the genuinely human, which does not have a market value; from here, we have its unqualified devaluation and the advent of anti-humanist and post-humanist philosophies, which triumph today.

\section{Economicism: The Hegemony of "Exchange Value" over "Use Value"}

The shift from the oral to the visual, from the qualitative to the quantitative and from the analogical to the disjunctive, led to the devaluation of the aspects related to culture and politics in favor of strictly economic aspects, which then came to be considered as the basis of civilization. This can be seen by analyzing the inversion, which has been preached within modernity concerning human relationships, as they had been studied by Aristotle in his Nichomachean Ethics and in his Politics ([3], pp. 25-34).

Aristotle, in his Politics, established a hierarchy of human needs according to their importance and duration, giving rise to the distinction between politics and economics. The former referred to the highest order of needs, those related to "good living" and which touch on the need a human being has for recognition, immortality or permanence in memory. Such needs are usually attained by the exercise of the spoken word, since a human being is the only animal who has the power of speech [17].

Economics, whose etymological root is underlined by Aristotle, refers to the nómos of the oikós, of the home, and its primary focus is not so much relationships between people, but rather relationships between people and things. What is important here is the satisfaction of basic human needs, in this case either of a strictly biological and ephemeral nature on a daily basis, such as food, or something more cultural and stable, such as clothing and shelter. The basic activity that characterizes economics is utilization or usage (crea), and what Aristotle ponders in this sense is essentially care, good administration ("household management"), as he argued in Nichomachean Ethics [18]. From this, it follows that economics should so clearly appear to be linked to ecology and to the correct use of things for the satisfaction of needs. Equally, economics thus understood appears as a presupposition for politics. Without a minimum of goods, it is impossible to practice virtue. Without resources, as regards food, clothing and shelter, there is no room for thinking about recognition or aspiring to be remembered, except by inadequate means.

Chrematistics is quite distinct from politics and economics; its focus is to acquire and potentially accumulate goods by means of commerce ([17], 1256a-1257a). As compared to what happens in economics, the fundamental concept is not the "use value", the worth of a thing measured in terms of satisfying human needs, but rather the "exchange value", the purchasing power a thing has to enable one to acquire other things. Aristotle distinguishes between "retail chrematistics", which can be justified in order to acquire goods necessary for survival, and "wholesale chrematistics”, which arises when the aim of augmenting one's goods and money has overreached the mere satisfaction of one's basic needs ([17], 1258a).

Chrematistics, thus understood, leaves the door open for "hybris" (impietas, perversion) by conceding more importance to the "exchange value" (the sole value that money has) than to the "use value” ([17], 1258a-1258b). We have here a true perversion. Such a perversion reaches an extreme 
when money, already overly valued, is no longer a mere mode of exchange and is transformed into a creator of more and more money (this is where the Roman word pecunia comes from). Such is the function of profiteering loans, which, for Aristotle, denaturalizes economics: "Of all the types of traffic this is the most anti-natural” ([17], 1258b).

The change introduced in this point by modernity could not have been more radical. Karl Polanyi is fully justified in calling this change The Great Transformation [19]. Such a transformation is linked to the hegemony that the market acquires as the central institution of society. The market started to arise as a marginal activity of the poor and vagabonds on the outskirts of cities foris burgos (faubourg), from the eleventh century onwards, but the norms regulating it were still external to the market itself, based on ethics, especially the theory of the just price [20]. The Great Transformation only came about in the sixteenth century with the total independence of the market world vis-à-vis the ethical and social horizon. This was the result of using new juridical tools, such as bills of exchange, which appeared in order to avoid the canonical sanctions imposed against crimes of usury.

The hegemony of the market and the prevailing of chrematistics (accumulating money) over the real economy (use value of goods) constitute the nucleus of the new political philosophy, which modernity introduced. This radical change of perspective, as explained by the German economist, A.O. Hirschman, is consolidated on the basis of a new conception about the role of human passions in social life and of the effect—fostering or inhibiting — that individual interests exercise over them [21]. Classical thinking, in effect, always took into account the role of passions in the life of man. However, it maintained in clear terms the exigency of controlling all of these passions, so that the individuals can achieve completeness as human beings and with it their real freedom and perfection. Passions, as regards human impulses, had to be controlled by reason and subject to will. However, as confirmed by the majority of thinkers, from the Renaissance onwards, we witness a loss of the ontological and ethical perspective that leads to a situation in which the fundamental component of man is considered to be passion, and precisely for this reason, it is impossible to control all of them. From here on, what we see are attempts at a kind of cross play between passions in which the presence of some end up excluding the influence of others: "passions set themselves against each other and one of them can act as a counterweight for another” ([21], p. 34). This desire to use some passions against others is linked to the belief that they do not all play the same role in the conservation of social order. In other words, passions can be identified as more or less expedient and, on the basis of this, can be considered beneficial or pernicious in the social context: beneficial would be those that promote stability, allow themselves to be calculated and are pacific; pernicious would be those marked as representing the opposite characteristics ([21], p. 39).

This is the line of thinking that Hobbes follows in Leviathan. The basis of the social pact is, on the one hand, the elimination of violence of wild passions — such as thirst for glory or power — and on the other, the satisfaction that: "The Passions that encline men to Peace, are Feare of Death; Desire of such things as are necessary to commodious living; and a Hope by their Industry to obtain them” [22]. Hobbes's political philosophy, by making fear of death and the profit motive the mainstay of social stability, offers a completely inverted view of classical political philosophy, which was based on freeing man from fear and searching for the common good [23]. In any case, what was to be an almost unanimous view among the authors of the period was the proposal that sustains fostering the so-called pacific and benevolent passions, among which the profit motive is given a prominent position (and the 
free commerce that facilitates this), to ward off the danger of pernicious passions, above all the thirst for power and sexual libido. All of them came to state that the search for personal profit is enormously beneficial for the stability of the political community, in that it corrects the principal defect in man: fickleness, as Machiavelli reveals in Chapter 17 of The Prince. In short, the search for financial profit accordingly appears as the best and most appropriate means by which to engender the stability and well-being of the political community ([21], p. 89).

Consequently, the desire to accumulate wealth (traditionally called greed) was no longer considered to be harmful and pernicious (a vice), typically associated with people who were detestable (the miser is a proverbial figure in literature) and was now considered to be a beneficial passion: one which guarantees the protection of interests, "self-interest". This new way of seeing the profit motive gave rise to a profound change in the mentality: to pursue "self-interest" becomes the inescapable premise of rationality, and those who do not pursue or defend self-interest do not act rationally and ostracize themselves from society. However, in the context of a society expressed in terms of the market, to defend self-interest means maximizing profit (financial profit) in all acts.

It was Bernard Mandeville, with the publication in 1714 of this famous work, The Fable of the Bees [24], who first gave form to this conceptual change (seventy years before Adam Smith developed his theory of the "invisible hand"), claiming that the general good emerges from private vices (such as greed), because the market converts the pursuit of personal interests into well-being for everyone (each person gets what they are looking for). This mentality impregnates all thinking in modernity and results in defining human beings in terms of their relationship with the market: in other words, like the homo faber: "the subject who produces in order to exchange". The definition of man as a "being who exchanges", put forward by Adam Smith, becomes paradigmatic: "Nobody ever saw a dog make a fair and deliberate exchange of one bone for another with another dog” [25]. This meant a profound change compared to the anthropological conception found in classical philosophy: the essence of what is human no longer lies in the order of being and is now displaced to the order of doing, the capability to create things that are not consumed, but rather used and exchanged. Benjamin Franklin was to define this in more precise terms: "Man is a tool-making animal" [26]. In other words, what is truly valuable is that which has a market value, which can be exchanged, i.e., which has "exchange value". The general acceptance of this proposal converts the market into the center of social life and the mainstay of political action.

This hegemony of the market also had major repercussions for the triumph of the formalist conception of law. In an instrumentalist world that gives exclusive value to tools, it is logical that law only appears as justified to the extent that it can become yet another tool; that is, a means that serves different ends (in this case, at the service of the market). Economicism thus drains law of any rational and ethical reading of law and changes it into an instrument at the service of the class that represents the development of the economy: the bourgeois economy. Adam Smith was most explicit when he claimed that the presence of what is legal can only be justified in terms of the defense of the owners against those who could potentially subvert their property. We can read this in his The Wealth of Nations that: "Civil government, so far as it is instituted for the security of property is, in reality, instituted for the defense of the rich against the poor, or of those who have some property against those who have none at all” ([25], Book III, chap. 2). 
The primacy and exaltation of self-interest was also to result in investing in a moral ranking of wealth. In effect, classical thinking always defended the superior ethical value of poverty-to have the goods that are necessary for subsistence and to forgo what is superfluous to one's needs-proposing this as an ideal life from the stoics to Christianity [27]. The economicist conception of modernity proposes the very opposite: wealth is the ideal in life. The result of the subsequent influence of protestant thinking was to bestow wealth with a religious dimension, as illustrated by Max Weber, converting it into a sign of divine predilection [28]: the rich have been blessed by God, while the poor have been punished and repudiated and only deserve to be scorned. The poor are wretched. Those who do not have goods end up losing their dignity and being ostracized.

The wealth motive also ends up shedding its religious connection and secularizes itself ([28], p. 69) and, with it, liberating the market from all ethical ties. It was the neo-classical school towards the end of the 19th century that coined the model of the homo oeconomicus with which the economy finally divorced itself from ethics, identifying rationality as maximizing profit. This is a profit that has progressively become more calculable and predictable with the increasing use of mathematics in the economic sciences [29]. Therefore, personal interest and personal profit are consolidated as the most relevant motives of human action, whose legitimation lies in the belief that the egotistical behavior of everyone will lead to general prosperity.

This independence of the market with respect to ethics constitutes, precisely, the foundation of the modern science of political economy, a term that was rediscovered in the seventeenth century by Antoine de Montchrétien. However, the usage of this term is inappropriate, since for all intents and purposes, this "new science" is nothing other than the theory of trade and money, that is to say simple chrematistics. Its method is that of arithmetic, as pointed out in the title of the important work by Sir William Petty, Political Arithmetic (1676): only the visual and the quantitative count, that which can be measured and counted; the rest is repudiated [30].

This quantitative paradigm implies important consequences vis-à-vis the vision of human beings and in their relationships with nature. Firstly, the negation of differences and hierarchies among human needs leads to confusion between real needs and unbridled desire. This originates the conception of man as homo oeconomicus. What counts is the indefinite enrichment of individuals, since the well-being of society will be generated thanks to the famous 'invisible hand' of which bourgeois economists have been incessantly speaking since Adam Smith and which is nothing other than the ideological and profane utilization of the idea of Christian Providence aimed at banishing the sentiment of compassion in view of the surrounding poverty. With the absence of a hierarchy among human necessities and by not appreciating anything except what is visible, accumulation becomes an instrument to attain an impossible and pathetic immortality: “[The] Modern individual cannot support economic equality because he has no faith in his own transcendence, in the symbols of spiritual immortality; only physical value can provide him with liberation from death” [31]. Thus, accumulation appeared as the remedy for recognition.

As said earlier, the extent to which what is valuable is determined by "exchange value" means that all things finally lose their intrinsic value and are reduced to their monetary value. This produces a relationship between the subject and things, which is no longer based on ethical considerations — a good or bad choice-but rather, based exclusively on chrematistic considerations: more or less profit. The conception of the homo oeconomicus means precisely excluding all references to ethics and all value 
judgments from the sphere of choice by the subject and to identify rationality with decisions leading to maximizing profits. Adam Smith explains it in the following terms: "In all countries where there is a tolerable security, every man of common understanding will endeavor to employ whatever stock he can command, in procuring either present enjoyment or future profit. If it is employed in procuring present enjoyment, it is a stock reserved for immediate consumption. If it is employed in procuring future profit, it must procure this profit either by staying with him, or by going from him. In the one case it is a fixed, in the other it is a circulating capital. A man must be perfectly crazy, who, where there is a tolerable security, does not employ all the stock which he commands, whether it be his own, or borrowed of other people, in some one or other of those three ways” ([25], Book II, chap. 1).

The underlying idea that governs the behavior of homo oeconomicus is strictly as follows: those who do not maximize their profits (increase their earnings) are "perfectly crazy". Additionally, this maximizing can be quantified strictly in economic magnitudes: either through savings, accumulation or exchange. "Intelligent” (rational) decisions always lead to maximizing the profits of certain individuals, who are both egotistical and calculating. The problem lies in the fact that the homo oeconomicus model, reductionist by definition, was conceived for the study and research of the behavior of individuals in an exclusively economic context. However, modernity extends this model to include all human reality and takes for granted that everything humans do only makes sense "in" and "for" the market, and the basis for this rationality is predominantly economic and not ethical [32].

When utilitarian philosophy intruded into the sphere of economic analysis, it took this somewhat rudimentary interpretation of human behavior and raised it to the category of scientific analysis. In effect, the principle of utility proposed by Jeremy Bentham ("the greatest happiness of the greatest number") and his proposal for a new ethic based on "maximum pleasure and the minimum degree of pain" (good is equated with what is useful, and useful with what increases pleasure and minimizes pain) diverted the analysis of rational behavior towards a calculation of utility, that is, towards pondering the consequences of each decision: "Nature has placed mankind under the governance of two sovereign masters, pain and pleasure. It is for them alone to point out what we ought to do, as well as to determine what we shall do. On the one hand the standard of right and wrong, on the other the chain of causes and effects, are fastened to their throne. They govern us in all we do, in all we say, in all we think" [33].

From this viewpoint, those who are rational are those who make decisions in terms of "opportunity cost": each option (to be here or there, work on this or that) inherently and simultaneously entails some gain and some loss. Therefore, those who are utterly rational are those who know how to choose, in terms of opportunity that which provides them with greater utility (maximum welfare and minimum suffering) between the various options possible. Maximizing utility thus becomes a criterion with a much greater bearing to justify rational decisions, although translating this into strictly economic terms continues to be a maximum profit and minimum cost as regards both production, as well as consumption of goods. In this way, the market not only makes this possible, but also forces individuals as regards their welfare to opt for a maximizing behavior. If the individual acts otherwise, this results in marginalization.

With the introduction of the utility calculation, economicism definitively excludes all moral references to human behavior and manages to reduce decisions to chrematistic terms, even those that are not directly in pursuit of economic profit, for example, desire for recognition, charity, altruism, the 
search for glory, honor, etc., since the economic agent can be assigned utility for behavior that pursues these variables. In effect, utility translated into terms of maximizing pleasure can be achieved by owning goods, as well as divesting oneself of them. The determining factor is the amount of welfare that it produces for the subject. Those who commit suicide maximize because they value death more than life; the acetic values the simple life over consumption, whereas the monk values silence more than communication, etc.

The end result of reducing all reality to a calculation of utility also includes human beings themselves. This is how Gary Becker (Nobel Prize in Economic Sciences) saw it when he analyzed the behavior of the family in these terms, proposing that children should be considered "long-term consumption goods" that produce utility; the most expensive are those of a higher quality and facilitating their exchange [34]. In short, the explanation of human behavior from the premise of a rational agent that acts by maximizing its utility, however this may be interpreted, eliminates all manner of moral conception of human nature and opens the door to nihilism, which would be hallowed in the post-modern period. If we take a classic example, the decision to produce "canons or butter" (an entirely banal question) no longer belongs to the terrain of moral deliberations, but rather to the market. Put another way, the decision is qualified as rational to the extent that it responds to the calculation of utility designed to maximize well-being benefits. This is why the market (in the positive sense) ends up being qualified as a neutral mechanism; that is, something that is desirable not for ethical reasons, but rather for "technical" reasons, since it guarantees all individuals Pareto optimality.

The very idea of homo oeconomicus - the conception of human life as something that only has meaning in terms of the individual procurement of monetary gain-assumes that it is the rhythm of production, and nothing else, that guarantees the appropriate organization of society. Usage has no value, only exchange does. This form of social organization uses "exactness" as its model. The motto of the modern organizer is that society has to work like clockwork. From this, as Schumacher has pointed out, "the ideal of industrial Modernization would be to eliminate what is alive, including human life, and to transfer the production process to machines since these can work with greater precision and can be wholly programmed, whereas this cannot be done with people" [35]. However, in the meantime, while we have to continue relying on human labor, this work has to be regulated to the fullest. This gave rise to Chesterton's pointed remark that, "the modern planner is only concerned with workers in the same way as with clocks: when they stop" [36]. However, this concern is limited to voluntary slow-downs or strikes and not extended to forced lay-offs or unemployment, since the latter is increasingly contemplated as a requirement of the system itself and needed to avoid greater break-downs.

Exactness, the condition of growth, generates (along with the concentration of capital) a detrimental effect on human beings. This can be observed especially in two spheres: the rupture of the balance between science and art, between work and leisure; and in the rupture between production and consumption. The first harmful effect can be seen by reading the works of Claude Henri de Saint-Simon (1760-1825), who is the prototype technocratic organizer. In his various writings, and most especially in his Industrial System, Saint-Simon points out the opposition between the useful work of scientists, engineers, bankers and industrial workers, who increase wealth by directly satisfying economic interests, and the useless work of parasites, such as philosophers, theologians or jurists, which is solely guided by sentiments and which limits itself to reproducing wealth, but without increasing it. Thus, whereas the former are good for something clear and precise, the latter are lost in 
empty realities [37]. Saint-Simon proposes conceding power to engineers and bankers, so that they can fight to eradicate all useless activities and favor imposing productive work. Their mandate would be beneficial, because their interests coincide with the interests of the collectivity ([37], p. 1044). It is a matter of having them, through their stimulus, convert society into an authentic "megamachine" dedicated to production. This would entail the increased division of labor, prescribed from Smith onwards, and a substantial increase in the number of working days. As Mumford recalls, until the beginning of the eighteenth century, more than half of the days of the year were feast days [38].

The other harmful effect would be produced between the model of the producer and the model of the consumer. This was developed by Alvin Toffler: “The same person who as a producer was spurred along by his family, his school and his boss to renounce to gratification, to be disciplined, controlled, restrained, obedient, to be a member of a team, was equally spurred along as a consumer to seek immediate gratification, to do away with discipline, to seek his own individual pleasure, in a word to be a completely different type of person” [39].

This contradiction of the "modern world" is due to its incapacity to distinguish between two realities that are apparently closely related, although, in fact, they are quite different: "poverty" and "misery". This distinction has been sketched with incomparable vigor by Charles Péguy himself in "De Jean Coste". Poverty, akin to Horatio's paupertas, would be the state in which one would have enough to live, without luxury, but with decorum. It is a type of purgatory that makes human beings understand their limits and opens them to love and care for others. Misery, akin to Horatio's egestas, is, on the contrary, a true hell that one lives through in a state of authentic despair with regard to tomorrow and from which it is urgent to free mankind [40].

Modernity is not capable of understanding this distinction due to its quantitative characteristic based on the criterion of "sufficiency" to satisfy needs. It can only distinguish between having a lot, wealth, a model to be emulated, and having little, a model to be avoided. This indifference regarding the distinction between poverty and misery impedes the struggle against the roots of the main present-day type of economic marginalization, unemployment, since it refuses to see this problem as the result of the lack of solidarity and the unjust distribution of both income and the number of working hours. In this manner, the new technologies serve to increase the misery of those who cannot supply anything else but the "labor of the body", which is disdained as something unnecessary.

Economicism tends to reduce the dimension of need to the sphere of economic resources. It has also caused the devaluation of "caretaking”, in accordance with the primacy of chrematistics. This is very closely linked to what has become known as "sexism": the lack of consideration for tasks that were historically entrusted to women. These tasks were directly related to configuring and protecting humanity in its dimensions of greatest indigence, and therefore, they were of capital importance. However, due to their lack of exchange value, they were considered inferior.

In the devaluation of caretaking, there is also the conception of human beings as homo labilis: the tendency to not see life as anything else but the occasion for immediate pleasure and, therefore, shunning anything that could imply abnegation, dedication or sacrifice vis-à-vis others. This hedonism, so closely linked to the chrematistic mentality, at best favored the bureaucratizing of such caretaking, shutting it up in more or less comfortable ghettoes and leaving the radical indigence of the human condition on the fringe out of range from social visibility. 
The failure of “economicism” was already underlined by Fritz Shumacher in his most famous book, Small is Beautiful, published in 1973 with the significant subtitle: A Study of Economics As If People Mattered [35]. After the publication of his posthumous book, A Guide for the Perplexed [41], the value of his thinking became more striking. What is most fascinating about Schumacher's contribution lies in the courage with which he confronts the modern theories of the economists who consider the extension of the market to be a solution for all problems, whereas Schumacher stresses that the market itself is the source of the basic insufficiencies of modernity: "The market only represents the surface of society and its meaning refers to a momentary situation, such as it exists here and now. There is no deep delving into the essence of things or into the natural facts that lie behind them. In a certain sense, the Market is the institutionalization of individualism and of irresponsibility” ([35], p. 44).

Schumacher stresses that the greatest limitation of the market paradigm lies in its eradication of the qualitative, provoking important consequences in the comprehension of human affairs: "In the market, for practical reasons, there is the suppression of innumerable qualitative distinctions that are of vital importance for individuals and society and that are not allowed to come to the surface. Thus does the reign of quantity celebrate its triumph in the Market. There everything is made equal to the rest. To make things equal means to give them a price and to make them interchangeable. To such a point is modern thought based upon the Market that what is sacred (the person) is eliminated from life because there can be nothing sacred in something that has a price” ([35], p. 46).

\section{Decadent Post-Modernity: Techno-Scientific Anti-Humanism and Economicist Nihilism}

The current cultural situation continues to distinguish itself by the extraordinary influence of post-modern discourse, in its most decadent version, as a response to the (still open) debate on the crisis of modernity and whether the fundamental theses of the Enlightenment are still applicable: the absolute rationalization of the world and society by means of science, indefinite and irreversible historical progress, revolution as a fundamental method for liberating peoples and individuals, liberal democracy as the definitive form of political organization and the market as a guarantee of general well-being. The postmodern refutation of the Enlightenment thesis claims that, on the basis of historical evidence, none of these prophetic expectations have been fulfilled. In contrast, the magnitude of the "perverse" effects caused are such that, on balance, the 20th century is a far cry from being qualified as the most positive in human history. This explains the scope and degree of deception expressed in postmodern thinking [42].

However, it is not that easy to reconcile this theoretical verification of the failure of modernity with the present-day spectacle of uninterrupted technological progress and the omnipresent market that facilitate and promote an opulent life-style in the West and a fascinating array of artistic and cultural movements of all kinds. The most lucid hermeneutics of this apparent contradiction is perhaps that posed by the anthropologist and sociologist, Arnold Gehlen [43], and which could be summarized as follows: the premises of Enlightenment are dead, but their consequences live on. The name he gives to this is “crystallization”. Put another way, the two fundamental consequences of modernity live on, technological progress and the market. However, there has been an absolute disconnection between both realities and the common principles to which they responded in the premises of enlightened thinking: achieving the moral progress of humanity; and the definitive emancipation of the human being. 
In effect, widespread education and culture has not brought about a greater understanding between individuals and peoples (nobody now thinks that the sapere aude promotes the total emancipation of mankind). In politics the liberal democratic and bureaucratic socialism systems are preserved, because they have managed to generate functional systems, entirely regardless of their meager power of conviction. The sciences and technologies find themselves confined within a non-modifiable system subject to techno-structure, but separated from their vital aspirations. We continue to see that, despite the immense scientific work in recent decades, they have not produced one single innovation comparable to those by Max Planck, Einstein or Heisemberg. It is only in the field of human biology and cybernetics where there have been substantial advances, but under an ambivalent and disquieting cloud (the manipulation of the genetic basis of humans and loss of intimacy). Finally, in the areas of artistic and cultural production, the last significant contributions date to around 1910; but this process of subjectivization of art has already fulfilled its main expressive potential. There is not even room to speak today of “avant-garde”, because now there are no longer advances in anything, nor a resistance to make a break. According to Gehlen, we would have entered into post-history ([43], pp. 322-23).

From the context of this post-history state of affairs of consequences without principles (disconnection between technology-market-culture and humanist values) emerges the story that has made the deepest impression on the spirit of Western Europe: that offered by thinkers labelled "post-modern". This is a thinking that rises up against the hegemony of all-embracing, utilitarian and instrumental reasoning, but does not do so from an alternative rationality, but rather from a vital experience; that is, it acts as a spokesperson for a feeling of disenchantment, from the deception experienced by man today in light of the failure of enlightened rationality and, with it, the definitive failure of reason. Post-modernity, as stated by Lyotard [44], rather than a current of thought, is a "sensibility"; that is, an experience that has been forged in the heat of the profound cultural crisis fanned by the decline of enlightened reasoning. In this disenchantment and post-modern skepticism in the face of reason, two contributions fundamentally converge: that begun by the Italian aesthetes (Vattimo, Castoriadis) and that which originated from the French post-structuralists (Barthes, Baudrillard, Deleuze, Derrida, Foucault and Lyotard). Although both movements, in their attempts to prevail over modernity base themselves on anti-humanist and nihilist proposals, it proves paradoxical that they finally take up (surely to their regret) the two most significant elements of modernity, techno-science and the market, and integrating them into this so-called "post-modern sensibility". As will be explained later, the former openly focus on techno-scientific reality, even as a path towards post-humanism. For their part, the French post-structuralists incorporate economicist logic implicitly by reducing the subject to the pure irrationality of desire and reality to a pure fragment.

\subsection{The “Techno-Scientific Anti-Humanist” Dimension of Post-Modernity}

Postmodern sensibility states that modernity has not only generated disappointment at a theoretical level, but also great practical disappointment, hence its utter failure. Modern reasoning, which was hailed as the salvation of humankind and the means for man to achieve happiness, after a century of hegemony, has revealed itself to be dominating, enslaving and destructive for humankind. Seen from its technical dimension, it has created machines of destruction; and from its theoretical dimension, it has abetted in the legitimization of any kind of ideology and means, as long as it reaches its ideals, or 
variations of these. We are not looking at the practical failure of a sound ideal; instead, we have arrived at the necessary and inevitable consequences of theory, since Enlightenment is none other than theoretical domination, which becomes technical domination. Put another way, the failure of modern reasoning is not due to the fact that the means chosen are wrong, but rather that the very dynamics of modern reasoning have generated these consequences due to its mistaken and paranoid attempt to dominate and subjugate all reality ([44], p. 22).

Postmodern sensibility confirms this "cultural climate", which reflects disenchantment in the face of the failure of scientific and technical reasoning that has dominated the modern world and is committed to dislodging this "all-embracing reasoning" from its hegemony over reality. Along these lines, it proposes adopting an anti-enlightenment approach, which it has no reservations in qualifying as anti-humanist, subordinating the subject to a process of "deconstruction" "unmaking”. Think well, feel well, act well, according to this "episteme of unmaking”, means rejecting the tyranny of totalities, because totalization in any human endeavor is potentially totalitarian [45].

To fight against totalizing reasoning basically means to fight against the subject that it has forged. In effect, post-modernity expresses an ontological rejection as regards the subject produced by Western philosophy and rooted in Cartesian "cogito", understanding that this is the artifice of instrumental, totalizing and dominating rationality; it is the subject of the "will to power" hailed by Nietzsche. This is the subject that the humanism of modernity has placed as the center and absolute reference of oneself. To de-construct this subject necessarily involves adopting an anti-humanist position, because, as Gianni Vattimo states, in postmodernity, man is no longer the center; he is heading towards an unknown, towards " $X$ ”, or rather he is heading nowhere ([2], p. 23). In effect, it is humanism itself that has brought about the dehumanization of man: either because it has eclipsed humanist ideals in favor of man dominated by rationally productive techniques or because it has bureaucratized everything in social and political organization [46]. Olwald Spencer (1918) and later Ernst Jünger (1932) already admitted that our civilization was in decline given that our activities are no longer those of creation, typical of an early age, but rather those of technical, scientific and economic organization, which culminate in the establishment of a domination, which, when all is said and done, ends up being military ([44], p. 16). Heidegger himself, in his famous Letter on Humanism (1947), argues that the disenchantment of the world, its enslavement in the direction of technics and the servitude of humanitas towards mercantile rationality are not attacks against humanism, but rather the outcome of humanism itself; the uprooting of all that is natural for that which is cultural, the will of human rationality to dominate completely what is real [47].

This deconstruction process of the subject requires the dissolution of the foundation and, consequently, abandoning humanism. In effect, both in technics, as well as in metaphysics or in humanism, one always discovers a search for the foundation upon which reasoning is built and which is arrived at through reasoning. All said and done, any attempt and search for foundation is nothing more than the affirmation of metaphysics, and this always generates violence and domination. Here lies the error of humanism, having assigned man the role of a conscious subject; that is, a foundation of himself. This is why Vattimo states in clear terms that postmodernity means absence of foundation; the definitive prevailing over metaphysics, without having to feel remorse. The crisis of modernity is not solved with criticism, or with a new foundation, or with a new humanism; the only solution is to do away with all of them ([2], pp. 45-46). Heidegger’s anti-metaphysical position needs to be interpreted 
along these lines: not as a humanist yearning to return to be what we have forgotten, but rather as the history of a "long farewell to being", of an never-ending weakening of being, of a definitive prevailing over metaphysics. A radical "slimming of the subject" is a stage in the cure for humanism. The subject is a mask, a transmitted fable. This is no longer important: it is presence-absence in a society transformed more and more into a very sensitive organism of communication. In short, we inhabit a world that is no longer true, that has become a fable, and postmodern man has stopped being subject, has been left empty and has become a mask [48].

What postmodernity proposes is to promote what is human without a new humanism: "the possibility to truly facilitate all the "other" possibilities which make up existence" ([2], p. 30). The major values of humanism (being, truth, goodness, etc.) are fables, sagas, transmitted messages. One does not have to continue interpreting fables as truths, but rather "live the fabled experience of reality, and experience which is also our only possibility for freedom” ([2], p. 32). From here on, the door is left open to nihilism, which does not attempt to exalt absolute, total or metaphysical nothingness, but simply state the weakening of the founding being of traditional metaphysics. Vattimo defines this as the "situation in which man abandons the center to head towards X" ([2], p. 21). Postmodern man is nihilist, because he has understood that there is no meaning, there is no metaphysical foundation: “nothing remains of being as such" ([2], p. 22).

Techno-scientific reality, however, has great interest for this anti-humanist postmodernity, to the degree of considering it a powerful instrument for liberation and later self-construction of postmodern man. Science is not a fetish that is erected as a sole and definitive knowledge of reality, because then, "we would fall into the defects of metaphysics" [49]. Science must not set up fiction as reality, but rather it should help us to recognize that reality is fiction. In effect, the techno-scientific reality of the world, deprived of its dominating reasoning fetishist nature, takes on a liberating role, because it allows man to conceive of infinite possibilities of making and being made. Postmodern man (who Vattimo calls overman), who clearly belongs to the techno-scientific world, "finds in science and in technics the framework of external security within which he can liquidate all the structures, intimate and external, of domination” ([49], p. 142). In other words, science and technics must be used by the overman to free himself from all conditioning, including biological and genetic and, thus, escape the domination and subjugation that the structures of society have exercised over him, which is a pure fable. As Gilbert Hottois pointed out [50], techno-science exhibits multiple emancipating and diversifying aspects: a creativity of possibilities that allows the true realization of the individual.

The well-known and controversial essay by the German professor, Peter Sloterdijk, Regulations for the Human Park [51], works along this liberating affirmation line of techno-science. Originally, it constituted a response to Heidegger’s Brief über den Humanismus ("Letter on Humanism” [47]), on the fiftieth anniversary of its publication. The terms used in the text prove to be very revealing, particularly when defining humanity as a "human zoo park" and when speaking of "domestication” (Zahmüng) as the task of the new man, who must be like a "tamer of human beings". Defining himself as "simply Nietzschean”, he restricts himself to stating the failure of humanism and pointing out a new scientific truth: the convenience of "a domestication of man by man" in which modern genetics would play a decisive role. Therefore, we would find ourselves faced with a new man who has to accept the new power he has over himself, namely biotechnology: the opportunity to reform the properties of the species genetically. Furthermore, all of this is without this new man being subject to a higher authority 
(God, fate, etc.) in the exercise of this new power. This new man has little in common with Nietzsche's overman. He has moved beyond questions of good and bad, not out of disdain for the established order, but because this order has dissolved, and this can be very clearly perceived in the area of new technologies. The new overman is the man of the new technologies, especially biotechnology. With this, Sloterdijk assures us that this is not an attempt to return to the Nazi eugenic techniques (he was obliged to clarify this point in response to harsh criticisms). The issue that the man of biotechnology is overman means that faced with a technical action, with no fixed regulatory limits, objectives or sufficient guidelines, there is only room for a liberating dimension that is not subject to the metaphysical prejudices of good and bad ([51], p. 19). Arguing along these lines, he speaks of "cold objective thinking" and not confusing the new man with the worst Nietzschean vision of the overman (a kind of gigantic and carnivorous dominator), but instead the individual who is able to come to terms with the absence of foundations. This man is strong enough, as Nietzsche wrote in his Untimely Meditations, to "choose for himself his own mask" in an indeterminate and pluri-cultural world [52].

As we can see, the anti-humanist orientation of postmodernity ends up drifting towards a post-humanist conception, firmly upheld by defenders of the so-called "biolitical revolution" [53], for whom the human species has become a concept that can be revised, if not obsolete. For example, Tristam Engelhardt argues along these lines when he states that: "in the long term there is no reason to think that only one species will come out of ours. There could be as many species as there are opportunities to substantially remodel human nature in new environments as reasons to refuse to do so" [54]. From post-humanist writers, others emerge from the perspective of relativism, such as Richard Rorty [55], for whom we have to abandon the task of "establishing" supposed truths in ontology, metaphysics or religion, as Nietzsche had already suspected. Contemporary man has to go even further and renounce the idea that there are true or false answers to the questions we ask ourselves. He states that: "it is very likely that human creativity could soon run out and that in the future there is non-human world which eludes our endeavors to conceptualize” ([55], p. 178).

Gilbert Hottois [56] considers manifestations of human culture (history, art, philosophy, moral values, etc.) to be nothing more than attempts to symbolize or "encode" a reality in movement. Therefore, all concepts that accompany these attempts are relative, including the concepts of humanity or the individual. The attempt to fix and impose one of these concepts is completely contrary to techno-scientific development. What happens today is that philosophy can be seen as impotent and incapable of symbolizing or "codifying" the techno-scientific universe. He even speaks in ironic terms of the failure of deconstructive thinking (along the lines of Wittgenstein's linguistic games) to satisfactorily express being in the techno-scientific world ([56], pp. 112-20). This is why he proposes substituting philosophy for techno-scientific research and development linked to the market, since technics and money are the two major operators in the contemporary world: "It is the techno-scientific actors that continually invent and produce the future. Reality is de-constructed and re-constructed indefinitely under the sole driving force of technics and the market" ([56], p. 123). "Symbolic orders and hierarchies emerge in the chaotic space of global mercantile mobilization; they influence it for a given time and on a local basis, but cannot structure it in a lasting manner nor stabilize it at a global level. The power, liberty or desire for exchange and change know no limits” ([56], p. 159). Hottois ends by admitting that: "techno-sciences open up to a functional transcendence of the species: they allow for effectively overcoming the natural limits associated with the human condition.” ([56], 
p. 163). In short, the anti-humanism of postmodernity has drifted into a post-humanism that has located the idea of techno-science in terms of the final horizon of thinking. The refutation of all foundation has elevated science above itself to the point of coming to be seen as a kind of substitute messiah, a “default” ideology for a post-human future.

\subsection{The "Economicist Nihilist” Dimension of Post-Modernity}

The nihilist climate of postmodernity is particularly evident among the French post-structuralists (Barthes, Baudrillard, Deleuze, Derrida, Foucault and Lyotard), whose thinking paradoxically (and perhaps to their regret) contributes to consolidating the economicist logic of modernity, which is discussed below.

Post-structuralism appeared in France in a climate of skepticism with regard to the possibilities of "changing the world" after the two-fold failure in May 1968: student protest and the "Prague Spring". This skepticism was precisely the constituent cause of its scant originality (for authentic creation to come about, a minimum of enthusiasm is required) and explains how inadequate its attempts were to overcome modernity, given the fact that its approaches are narrowly linked to modernity, as openly acknowledged by post-structuralists themselves.

The link between post-structuralism and modernity presents a two-fold dimension. First, the epistemological dimension: the dissolution of truth in "text", or in other words, the denial of reality within the never-ending process of interpretation. Barthes and Derrida have insisted, more than anybody else, upon this aspect. Second, the anthropological dimension: the dissolution of consciousness in unconsciousness and the denial of the person in an indefinite number of masquerades. Deleuze and Foucault, in particular, have insisted upon this aspect. In both cases, however, the indisputable guides are the nihilism of Frederick Nietzsche and Stéphane Mallarmé ([3], pp. 86-90).

The post-structuralist authors propose "the text" as literary expression, a multidimensional aesthetic space in which a variety of styles (none of which is original) combine and are "contrasted" and in which the sign is dissolved in a nonsensical set of meanings, as opposed to the "work", which suggests an aesthetic whole fixed by an origin (the author) and an end (some represented reality or transcendental meaning) [57]. To support this primacy of the "text", they resorted to Nietzsche and Mallarmé as authors who defend an indefinite and unfinished interpretation, as opposed to Saussure, who had believed in the absolute existence of signs [58]. They draw an opposition between structuralist semiology and nihilist hermeneutics.

The reference to Mallarmé could not be easier or more clarifying [59]. In effect, for Mallarmé, writing is a mere game, in so far as "there is nothing before writing [...], no primum signum, nothing to imitate; everything is pure representation" [60]. This nihilism is what led Mallarmé to wish to replace the Bible with his "text" in which instead of order, memory and truth, what would appear is chance, randomness, necessity and games. "Literature returning to its source, which is art and science, would give us a theatre whose representations would be the true modern cult” ([60], p. 317). Derrida would exacerbate this playful aspect of writing by constantly resorting to "logomatics" and more or less ingenious play on words. The critique of the logos pays the price of reiteration and boredom.

Nietzsche, in principle, seems to be opposed wholesale to modernity [61]. Yet, his spirit basically coincides with that of modernism, a movement for which he declares his admiration in different 
passages for its principle of l'art pour l'art, which he considers to coincide with his own principle, whereby art is worth more than truth, due to its tendency to hide itself and to be opaque for the majority of people; in other words, for its elitism and its anti-democracy [62].

However, what is of special interest in Nietzsche for the post-structuralists as regards the epistemological aspect is that which he has in common with Mallarmé, such as his hostility towards what is finished and mature, which, according to Zarathustra, implies the "fear of life", in defense of what is fragmentary, and his view of philosophy as an indefinite interpretation [63]. It is this aspect that is stressed by Foucault [64]. In agreement with this view held by Nietzsche, "knowledge has not been made to understand but to make inroads [...]. The search for the origin does not found; on the contrary, it stirs that which seemed motionless, it fragments that which was thought to be united, it shows the heterogeneity of that which was thought to be in conformity with itself” ([64], p. 151).

The dissolution of truth in an indefinite interpretation that has no object constitutes the epistemological side of the same coin whose other side is the dissolution of the Self in the It. The attempt to unveil truth culminates in the unveiling of the subject, of the person. "The philological resolves itself in physiology” ([62], n. 20). Although the post-structuralist writers were influenced by the three "theoreticians of suspicion", Marx and Freud were accepted in so far as they were compatible with Nietzsche, that is to say, very weakly. Both were considered to be too mild when it comes to proposing the liberation of unconsciousness or desire. In Marx's case, it is matter of going even further by proposing a change from homo oeconomicus to homo ludens. In Freud's case, it is a matter of inverting the relationship he established between the Self and the It in agreement with his affirmation of "where the It is, there should the Self be", and of replacing it with another in which the It is completely liberated. On this point, the post-structuralists show themselves to be the followers of the authors belonging to surrealism and to the Freudian Left, and particularly of Marcuse's thesis in Eros and Civilization [65]. However, their guide, as we have said, is fundamentally Nietzsche himself.

The unmasking of Nietzsche would be anthropologically tantamount to the suppression of one's face, in the same way that epistemologically it would be tantamount to the elimination of truth. Instead of an integrated Self, what appears is the Dionysian plurality of characters, the "child" as "innocence and game”, or in other words “discontinuity, pleasure, appetite, violence, depredation” ([62], Preface).

Possibly the book that best reveals the decomposition, the detritus produced by the unconditional primacy of the principle of pleasure over the principle of reality, is that of Deleuze in collaboration with Guattari, The Anti-Oedipus (Capitalism and Schizophrenia) [66]. The dissolution of the Self, in turn, implies the dissolution of the recognition of the other. If the It is called to govern, then the other disappears in favor of a perverse and polyphorm desire. Here, all limits disappear, even the prohibition of incest, considered by contemporary anthropology as the universal taboo of taboos: the main manifestation of the passage from the animal to the human. By strengthening the dimension of desire, the recognition of the difference among individuals disappears. There is no room for the differentiation between a forbidden person (one's mother or sister) and a person who prohibits (a father or an uncle), but rather everything remains in a state of generalized indifference. Everything is indifferent and, therefore, everything is permitted. There is no room therefore for surprise when we consider that in the text what is exalted is the supposedly primitive savagery of an indefinite number of sexes, as opposed to any regulation of behavior, which would be anti-natural. Schizophrenia, stimulated by capitalism with its split between morality from the point of view of both the producer and the consumer, is not 
corrected, but rather indefinitely fostered as the sole exit in the face of paranoia, which would be provoked by the desire of personal integration and which would lead towards totalitarianism [67].

However, Nietzsche at times manifests his opposition to economicism. Thus, in both Unfashionable observations [68] and The Dawn of Day [69], he criticizes the world of appearance, of theatre, of representation, as something originated from the primacy of money, which requires a showcase. Moreover, in his Genealogy of Morals, he censures the belief in culpability as the mere imitation of a concept from the economic sphere: guilt is nothing else but a simple debt and the resentment that follows as a consequence of the primacy of chrematistics, which tends to think that everything has a price and that everything has to be paid for. For this reason, in Zarathustra, he recommends to his overman (“Übermensch") that he should "abandon the market” ([63], part IV, n. 1). As if this were not enough, the exaltation of the figure of the "child" as the key to the overman could make us think of a certain caustic critique regarding the enlightened ideal of "maturity", of "adulthood", of the "emancipation”, of the sui iuris.

However, postmodernity and Nietzsche himself (and, of course, post-structuralism), far from opposing the logic of chrematistics, can be considered as a radical off-shoot of the same. Two of its dimensions show this clearly.

The first of these dimensions refers to the primacy of the will and the subject's power of disposal, precisely the key to the emancipating message of Enlightenment. The novelty is to be found in the fact that the emancipating dimension and the subject's power of disposal have passed from the world of property and things to the world of the body. The title-bearer of the right of disposal is not so much the sui iuris, but rather the "child", that is to say the unconscious, the desire. There would be no hostility whatsoever vis-à-vis the emancipating ideology, but rather an extension of the emancipating process of the desire. Voluntarism without barriers would lead to the (anti-) Freudian ideal of the total liberation of impulses. What is disposable, and therefore in the ultimate instance, what is alienable, far from being reduced, becomes extended. This unconditioned disposition of the bodily would be taken advantage of by commercial interests.

The second aspect in which we can find chrematistic logic refers to the primacy of what is fragmentary and what is disintegrated over what is global and whole. This was mentioned earlier when pointing out the defense of schizophrenia , which was proposed as the sole remedy against paranoia by Deleuze and Guattari, both of them following (in spite of themselves) the logic of capitalism. However, it can be seen as the result of applying a scientific-naturalistic methodology to the human being. The decadent view of the human being as something "worth very little", which appears in the post-structuralist writers, dissolves the notion of substance and cause and reduces individual to a "succession of sensations". All of this, however, was already to be found in Hume [70].

The fragmentation of the person into successive instances would be, in turn, something that was derived from the pure bourgeois spirit. According to Karl Marx (whilst submerging himself wholesale in that same spirit), this tends to destroy all that is permanent by converting it into the ephemeral and eliminating all that is sacred, thereby promoting the extension of indifference within the human relationships. As Jameson points out, postmodernity coincides with the logic of consumerism. In effect, the transformation of reality into images and the fragmentation of time into a set of perpetual present moments are a replica or a reproduction of the logic of consumer capitalism [71]. 
It is possibly in the sphere of politics where the unchanging and reactionary character of the late modernist authors is better revealed. Politics is incapable of being understood by the post-structuralists, among other things, due to their incomprehension of the institutional, which derives from the primacy of the unconscious and the instantaneous. It is not at all a matter of only criticizing those "institutions" (which would be perfectly legitimate), which from Goffman onwards are designated as "total institutions" (prisons, psychiatric hospitals, military barracks), in which the individual is totally molded, but rather a matter of casting aside all that is institutional, in so far as it implies the category of “duration”. The juridical and the political would be pure repression, no matter whether they are the fruit of individual arbitrations, reflection or a collective consensus. Democracy turns out to be even more impossible in its two-fold appeal to the 'given word' and to the 'common good'. In effect, in agreement with Nietzsche, what is common to everyone is already in itself something that cannot be good ("what is common is never a good" ([62], n. 43), and therefore, the search for consensus is in itself negative. Therefore, democracy cannot be anything except “decadence” and "self-deception” [72].

Both politics and art would be nothing other than simulation, mere fiction. However, politics would be so in a deceptive, fraudulent manner, at least for the masses, whereas art would be so in a declared manner. The pretension of the truth of politics is what makes it especially odious, whereas art would be directly lived as a simple invention. Politics is nothing other than pure representation, pure theatre. Representation as a simple game is inevitable, and it is absurd to be morally outraged by it. The post-structuralists believe that we have unavoidably entered the age of the comedian, of the clown, as Robert Musil had already pointed out in his Essays [73]. Additionally, in a more or less cynical manner, they take part in this "sad spectacle" by means of their opacity, their "logomachies" and their play on words. It is easily understood that elitism, the scorning of the masses and submission to the consumer society characteristic of the post-structuralists, should have been presented as the true postmodernity.

The gigantic echo reached by the post-structuralist authors in the Western World only demonstrates the urgent need for a "change in human mentality" based on opening the door for a "new humanism"; a new mode of thinking reality from a "non-economical perspective”.

\section{The Alternative Proposals to Postmodern Nihilism}

As opposed to the nihilist trend employed by decadent postmodernity as an answer to the crisis of modernity, there are two other important lines of thinking, which, from radically opposed ideological positions, have attempted to offer a "humanist" response by re-affirming the identity of the subject and of values as a basis for building a just, rational and human society. The first concerns writers from the "Frankfurt School" who, following the ideological and methodological lines of critical Marxism, proposed a change to the epistemological paradigm, which leans towards reinstating enlightened reasoning as a primordial element for recovering the subject and the humanity of the subject. The second concerns writers who have been labelled "neoconservatives", whose thinking, essentially focused on the area of culture, considers a strategy of recovering Western spiritual values as a premise to re-incorporate a fragmented and disoriented society. Neither of these two lines of thinking, in my view, has managed to propose a sufficiently solid front against the relentless nihilist drift of Western societies under the indisputable primacy of technology and market. 
The most forceful attempt to confront a crisis of modernity comes from the Frankfurt School of writers (C. Offe, A. Wellmer, J. Habermas, K.O. Apel), who continued along the lines of “critical theory” begun by Max Horkheimer with the publication of this book Traditional and Critical Theory [74]. "Critical theory" confirms the predominance of techno-scientific instrumental rationality in contemporary societies, which, in the words of Marcuse, has produced a "one-dimensional man" model, which has been reduced to a mere cog in the techno-economic wheels of capitalism and has ended up being dominated by consumerism [75].

The dense compilation by Max Horkheimer and Theodor Adorno, Dialectic of Enlightenment (1947) [76] and the later work by Adorno Minima Moralia (1951) [77] were the culmination of this relentless criticism aimed at scientific reasoning as the sole foundation of human knowledge and practice that has taken place in the Western capitalist system. The critique of capitalism turned into a critique of Western civilization as a whole. Indeed, the Dialectic of Enlightenment uses the Odyssey as a paradigm for the analysis of bourgeois consciousness. In these works, Horkheimer and Adorno introduced many themes that have come to dominate the social thought of recent years; indeed, their account of the domination of nature as a central characteristic of instrumental rationality in Western civilization was given long before ecological and environmental issues had become popular concerns. The analysis of reason now goes one stage further. The rationality of Western civilization appears as a fusion of domination and of technological rationality, bringing all external and internal nature under the power of the human subject. In the process, however, the subject itself is swallowed up, and no social force analogous to the proletariat can be identified that will enable the subject to emancipate itself. Hence, the subtitle of Minima Moralia: Reflections from Damaged Life [77].

The most current representative writer following this line of thinking is Jürgen Habermas with his book The Theory of Communicative Action [78]. As is known, he believed that modernity is an "unfinished project", whose fundamental premises are still valid, but whose consequences today must be purged of reductionisms caused by the undue hegemony of instrumental rationality [79]. In the path of "critical theory", Habermas states that technical reasoning-instrumental or strategic reasoning - has been colonizing the other areas of human rationality, turning into the raison par excellence. He states that all of the processes of the "technification" of social life-politics, education, culture, etc.-illustrate the predominance of instrumental reasoning and, in tune with Adorno and Horkheimer, confirm that the intrinsic logic of "systemic" rationality is manipulation, the domination of the other by the other. The domination of nature becomes the domination of some human beings over other human beings and, finally, becomes a "nightmare of self-domination" ([79], pp. 151-59).

However, Habermas claims that the origin of the breakdown of modernity is not in rationalization as such, but rather in the failure to provide a "balanced" development and institutionalization of all of the dimensions of reasoning needed to understand the modern world. The solution, then, does not consist of renouncing enlightened reasoning, but rather rehabilitating other dimensions, which have been overlooked with the predominance of instrumental rationality. Emancipating projects in themselves are not harmful for humanity, but rather only insofar as they are invaded by manipulating and dominating reasoning. One has to "purge" this emancipating reasoning (“critical reasoning”) from the manipulating bias of dominating reasoning, which should confine itself to its specific sphere of domination and control of nature. In other words, each of these dimensions of reasoning has to be linked to the specific interests pursued by human society. Put another way, "knowledge" and "interest" 
need to be linked. Knowledge that is constructed (scientific-natural, historical-sociological or philosophical-theological) has to be very closely related to interests (domination, relationship or emancipation) present in society ([78], I, pp. 175-81).

On the one hand, modernity has turned scientific-natural knowledge, which is a response to the interest in dominating nature, into knowledge par excellence, while relegating knowledge that responds to interests concerning relations (social) and emancipation to a secondary role or (even worse) identifying these relations in terms of the former model. Consequently, social interaction and emancipation have been contaminated by unrelated knowledge and interests. The path that leads to solving the problems of the world today depends on liberating socio-historical knowledge and emancipating knowledge (and its corresponding practices) from a methodology and interests that do not concern them. In other words, when it comes to relations and emancipation, there are rational "alternatives", which are not manipulating and dominating. Here, Habermas proposes "communicative rationality”, which is based on a primary and shared use of language ([78], I, pp. 264-65).

Therefore, how is market and economic rationality built into this framework? Habermas's answer is somewhat disappointing. Despite his critical posture, in the Marxist vein of confronting capitalism, he settles for relegating economic rationality to the specific sphere of "market interests", seeing the market in terms of a "subsystem" that is developed on the fringes of communicative rationality. However, other than being critical, he finds it difficult to explain how to confront the reality of a market whose instrumental rationality constantly breaches the limits of the economic framework. In effect, under the influence of N. Luhmann and particularly T. Parsons, Habermas makes an approximation of the capitalist economy, conceiving of it as a subsystem ([78], II, p. 234). Habermas's thesis holds that in the early stages of modernity, Western European societies had to confront a new systemic problem: material reproduction in a context of growing social complexity, which made coordinating economic social action unfeasible through communicative action. The mechanism that finally solved this problem was the institution of the capitalist market, which emerged unintentionally from the interaction of monologically-oriented individuals. However, it managed to achieve the status of an institution by making economic action and material reproduction possible in the new context of a complex society ([78], II, p. 247). The market emerged as a neutral mechanism coordinating individual economic actions, which were driven by egotistical self-interest. In short, it can be seen as institutionalizing “instrumental action”, which proves functional for material reproduction in complex societies. It thus constitutes a new level of collective learning for human kind ([78], II, p. 249).

The capitalist market took shape in a process that could be described as natural. It did so by "disengaging” itself from the "life-world" (culture and values) as a self-regulated subsystem and by means of its own non-linguistic communication: money. This differentiation of the capitalist economy as a subsystem, in turn, implies a restructuring of the State in systemic terms, as a self-regulated subsystem working from the basis of "power”. However, for Habermas (particularly in his later work, Between Facts and Norms [80]), the structuring of the State as a system, as opposed to the capitalist economy, would need to build a political foundation through the prevailing channels of democratic legitimation in modern societies. Habermas' diagnostic is that the economic subsystem, once differentiated from the "life-world", tends to transcend its own limits (driven by the capitalist class strategy to confront the working classes, as he somewhat hazily explains) and project itself again over the "life-world" colonizing it. In other words, substituting "money" for communicative action as a 
means of social integration ([78], II, pp. 465-89). This brings about anomie, demoralization and loss of freedom, which can be seen in late capitalist societies already studied by authors from a wide range of disciplines, such as E. Durkheim, M. Weber or Th. Adorno. Habermas' criticism is thus limited to stating the excesses of the capitalist market economy, which has the tendency of going beyond its own sphere, coordinating instrumental action, and to trespass areas where it is should be prohibited, namely, social integration through communicative action. However, this is precisely the scenario in which we find ourselves: instrumental rationality, which is emblematic of the market, has burst its banks, and neither has Habermas found the way to hold it back, because money (the non-linguistic means of instrumental relations) proves to be incompatible with communicative rationality, which is characteristic of the "life-world".

Habermas' proposal had already met resounding criticism in his first work published by his disciple, Axel Honneth, The Critique of Power [81]. Honneth questions Habermas' adoption of basic suppositions of the systems theory, because to consider the economy as a subsystem cleanses it of all political and moral components, idealizing it as a sphere, which is solely characterized by its institutionalization and non-adherence to regulations and instrumental action ([81], p. 419). Despite this characterization of the capitalist economy as a subsystem in functionalist terms, Habermas tried to update the theses of Karl Marx and George Lukács concerning the inherent reification in capitalism. The result was clearly unsatisfactory, as it bestowed upon the economic system a character of nonadherence to regulations and the capability to govern itself, which placed it out of reach from critical capacity of democratically constituted social will ([81], pp. 373-81). For Habermas, the economic subsystem as such cannot be criticized or transformed by the politically organized collective. All that is left is to question its excesses, its transgression of the limits placed on it (the material reproduction of society and trespassing into areas that should remain off limits (symbolic and social reproduction). That is, Habermas managed to make a topic of functional and structural imperatives of the market economy at the cost of shielding them from any criticism and attempts to in-depth transformation, by conceiving this economy model in systemic terms. In other words, in terms of a consolidation that cannot be de-differentiated and furthermore neutral from the perspective of regulations, and so, it cannot be set against any regulatory principles ([81], pp. 394-416). In short, Habermas puts forward a kind of acritical theory of capitalism, since he is only theoretically fit to question the excesses, but not its constitutive structure.

It is precisely for this reason that Habermas encounters problems integrating the globalization phenomenon (with its multiculturalist and economicist reality) into the universalizing proposal of communicative rationality. Habermas readily acknowledges the radical novelty of globalization in The Postnational Constellation [82]. However, he does not accept the consequences that this radical change of the economic, social and political context has for his theory of communicative action, which is still designed as a contra-factual response to the challenges of social integration, which arise from the "legitimation problems of late capitalism" [83].

As is well known, for Habermas, societies have to be conceived simultaneously as a "system" (institutions, society) and as a lebenwelt "life-world" (the subjective world of values and culture), which provides the regulatory resources to set the moral standards of the system. Communicative action is what makes a point of rational connection possible (symbolic consensus) between the "life-world" and the formal world of the "system" constituting a common objective with universal 
pretensions ([78], I, pp. 179-80; [82], pp. 167-68). Habermas confirms the existence of a "world system" along these lines. However, he also states that the globalization of the "system" does not run parallel to an adequate social integration of the "life-world". This proves to be extremely problematic for his thesis. In effect, the enormous fragmentation of the "life-world" (multiculturalism) obliges him to acknowledge that in the "world society", there is a systemic formalization, but not a social integration, which would provide identity. The result is an insurmountable dualism between "communicative action" and "system" that is unable to explain multicultural social links, not only in the global arena, but even in the national arena itself. In his theory, individuals and peoples who live in real interaction are effectively situated in different societies and in different "evolutionary states" to the degree that their "life-worlds" are different. However, this contradicts daily contemporary experiences. In summary, the originality of the recent globalization tends to break with the socio-evolutionary dynamic with which Habermas rationalizes both culture and society. Therefore, in this new scenario, in which various cultures live together in various socio-evolutionary stages, it is very difficult to conceive of communicative action producing social integration in the context of a socio-evolutionary process of progressive rationalization of culture and society. Furthermore, all of this does not take into consideration that the daily practice of social integration in first world cultures tends more towards a kind of "pragmatic irrationalism" rather than towards a socio-evolutionary process of rationalization.

Finally, as pointed out by Spaemann, his advocated methodology of "discussion free from domination" (Herrschafstfreiheit), which hardly goes beyond the pragmatic plane, is based on the fundamental categorization of the subject as pure relation. That is, communicative rationality ends up incorporating a subject into the system whose "life-world" (identity) is totally available, since the system favors consensus even above the subject itself: the discrepancy cannot easily be integrated into the system [84]. Additionally, to state that the identity of the subject is something that is substantially available does not constitute a very solid argument in the face of the nihilist direction posed by the postmodernists.

The second line of alternative thinking to the nihilism of decadent postmodernity is that argued by writers labelled as "neo-conservative" (neo-con), from the American arena. The intellectual roots of the neo-con movement can be traced back to the 1940s, with writers, the majority of Jewish origin, with a Marxist and Trotskyist background, such as Irving Kristol, Nathan Glazer, Daniel Bell, Seymour M. Lipset, Daniel Patrick Moynihan, among others. Liberal Catholics also joined the movement, such as William Bennett and Michael Novak, and then later, others, such as P. Berger, Th. Lukmann and J.R. Neuhaus [85].

In the 1960s, neo-con thinking burst on to the scene grouped around the journal, The Public Interest, founded in 1965 by Irving Kristol and Daniel Bell. It is in this publication that the neo-con began to cloak the traditional conservative opinions of the language of the social sciences and took up much of the theses of Leo Strauss, of Jewish origin and professor at the University of Chicago. Strauss' thinking is grounded in the idea that liberal democracy, with its emphasis on individual liberties, has led Western societies into decadence and disaster. However, Strauss did defend liberal democracy in the face of communism or fascism and publically aired his admiration for Churchill for opposing these totalitarian regimes. Strauss was deeply concerned that the philosophical crisis of modernity could undermine the Western world's confidence in itself. This accounts for his insistence on taking seriously and understanding the Western philosophical tradition [86]. 
Strauss taught that liberalism in its modern form contained within it an intrinsic tendency towards extreme relativism, which, in turn, led to two types of nihilism. The first was a "brutal" nihilism, expressed in Nazi and Marxist regimes. In On Tyranny [87], he wrote that these ideologies, both descendants of Enlightenment thought, tried to destroy all traditions, history, ethics and moral standards and replace them by force under which nature and mankind are subjugated and conquered. The second type-the "gentle" nihilism expressed in Western liberal democracies-was a kind of value-free aimlessness and a hedonistic "permissive egalitarianism”, which he saw as permeating the fabric of contemporary American society [88]. In the belief that 20th century relativism, scientism, historicism and nihilism were all implicated in the deterioration of modern society and philosophy, Strauss sought to uncover the philosophical pathways that had led to this situation. The resultant study led him to advocate a tentative return to classical political philosophy as a starting point for judging political action [89].

For Strauss, the time had come for elite to rise up and prevail over the weakness and lack of social cohesion caused by relativism induced by post-Socratic philosophy. The main tool employed by these new elite would be an artificial mythology constructed around the notion that the United States enjoyed a unique and well-established destiny in the control of the ignorant masses through deception, religious fervor and perpetual war. This mythology, or "Straussian text”, would have an "exoteric" meaning, accessible to the average reader, and another "esoteric" meaning, the true meaning aimed at its real target readers, namely the social hierarchy. For Strauss, the rebirth of modern societies had to be led by a caste of apt politicians prepared to spread these myths with conviction, the purpose of which was to furnish the lives of the ordinary people with purpose and meaning. In this enterprise, these politicians should back themselves up with absolute moral or religious values, so as to snatch society from the grips of relativism. A good politician, however, did not necessarily have to believe in these values, even those religious ones; appearances would suffice ([88], pp. 23-29).

One consequence of this proposal is reflected in the adoption of "American exceptionalism" as a political principal. This was a concept that had already been developed by Alexis de Tocqueville in Democracy in American and that for neo-con thinking constitutes a profound influence on American national identity, on occasions linked to the conviction of a providential destiny. In effect, the exceptionalism historically has been influenced by a messianism, both religious (God is on our side), as well as secular (our values and institutions are the best). As a consequence, the neo-cons legitimized the moral imperative of spreading this message to the rest of the world on the basis of this exceptionality of values and the American political system [90,91].

While neo-con thinking is mainly occupied with theorizing about foreign policy, its approach to economics leaves no room for doubt: free market and the development of capitalism, although without adopting the thesis of Hayek's radical neoliberalism, which entirely excludes all forms of public intervention in questions of the well-being of citizens [92]. His economic thinking lies in the separation between morality and market: the correct functioning of the market is based on the existence of strong moral convictions in individuals; but morality has to be looked for outside of the market and is only found in tradition. The market must provide individuals with material goods in an efficient manner, but lacks a moral criterion that can guide them along the right path in order to satisfy their needs. The market is only part of human life, but proves fundamental, because the breakdown of the market causes social disintegration [93]. 
In effect, neo-con thinkers maintain the market principle as their main point of reference, that is the free exchange of goods is the principal factor for progress and social development. However, they point out that the capitalist system is not altogether good, because it is going through a "spiritual crisis" that is causing the breakdown of society. The fundamental ill of this system is the "liquidation" of ethics; in the elimination or disappearance of the traditional values that sustain the capitalist economy. This "liquidation" of ethics has resulted from a profound cultural crisis linked to currents in postmodernism that propose styles of life that differ from traditional styles of life: instead of promoting workers who are disciplined and embrace order, they encourage individuals who are not in the least productive and quite hedonist; just the opposite of what the system needs. Therefore, one has to put an end to this hedonist malaise and recover the "productivity ethic", order and discipline that would guarantee the smoother working of the market and avoid social disintegration. This accounts for their attempts to endow the market with post-enlightenment legitimation, channeling techno-economic rationality towards a new capitalism. It is an attempt to reconstruct the nexus between morals and market with the rehabilitation of forgotten values from the Western Tradition, which is found in Judeo-Christian civilization and interpreted in puritanical terms [94].

In order to culturally (morally) mend the (American) capitalist system, only a moral and cultural step backwards is entertained. That is, we have to recover the values of times gone by (the puritan religious tradition) typical of capitalism; but without the anachronisms. To this end, we have to reinforce the compensating intermediate institutions: family, Church, personal friendships and freely-formed associations. It is these that can help to recover the values of puritan ethics: order, discipline and capacity for sacrifice. Here, a person finds value and is driven towards a behavior of solidarity in the social setting [95-97].

As can be seen, the neo-con proposal of looking back towards values and traditions, which accompanied the expansion of American capitalism in its origins, proves to be adulterated from the start, because what is transcendental and decisive in this proposal are not values, but rather safeguarding the market. Values only play an instrumental role as a justifying strategy for the hegemony of the market, but without questioning the basis of this hegemony: the maximizing instrumental rationality of profit. Although it seems obvious that there is a need to impose moral values on the market, this is not the path to follow in order to overcome economist rationality; suffice it to say that the growing marginalization seen in advanced capitalist societies, the increasing economic inequality between rich and poor countries and, particularly, the open defense of the arms race expressed by somewhat more than a minority of these thinkers.

\section{The Need for a New Humanist Story of "What Is Human”: The Rehabilitation of Ontology}

As has just been discussed, the weak alternatives to decadent postmodernity by the Frankfurt School and neo-conservative thinkers do not constitute real avenues to pursue in order to disable the reigning nihilism in society, which abandons human beings to the mercy of the manipulating and consumer games of technics and the market. In this extremely complex and growing panorama, which is subject to the tyranny of "exchange value", a humanist recovery of "what is human" is an essential and urgent intellectual undertaking; one which would restore the subject's most genuine and originating identity. 
In any case, as pointed out by the post-Jungian psychologist, James Hillman [98], to pose the task of recovering what is human nowadays, which would overcome anti-humanist criticism (a "post-modern humanism") means avoiding the "humanist fallacy". This consists of believing that man is the center and the measure of all things, in order to rediscover (as did Petrarch on the peak of Mont Ventoux, by Augustinian means) not man, but the spirit of man; and the spirit of man is not restricted to human experience, as its depth is, as Heraclitus pronounced, unfathomable. This is the great challenge to the humanistic recovery of what is human, if it is at all possible: to overcome the consequences of enlightened anthropocentrism, scientific objectivism, as well as irrationalist subjectivism, whose common denominator consists of reducing all that is real to empirical facticity. That is, to rediscover that the reality of what is human is not limited to what is bodily or psychologically human. If we are unable to connect with the transcendental dimension that bestows upon us genuine human identity, then all that is left is to endorse, along with Foucault, the definitive death of man (and with it, all humanism) and confirm the beginning of the Nietzschean post-humanity heralded in Sloterdijk's The Rules of the Human Park, which considers any attempt to understand the subject outside the scientific paradigm as futile, being the only paradigm that bestows upon us, through genetic engineering, the real capability to "tame man" and transcend our species as it is today towards the super-human and, thus, providing a remedy for the total failure of humanist values [51].

The prospect of developing a different narrative as regards what is human will only be possible, in my view, if we adopt the decision to "go back to the origin". This return should in no way be seen as a nostalgic or romantic conjuring up of the past, or as the patchwork of folkloric traditionalism. Neither is it an attempt in any way to evoke terminal authoritarianisms or late puritanisms. To go back to the origin responds to an attempt at radicality: to move forwards to the point of emergence. Additionally, the most radical for human beings is the meaning of their own humanity. Origin and meaning are two indispensable elements to connect with what is genuinely human. This tells us that to construct this new story of what is human must begin with recovering ontology. Basically, this consists of recovering the capacity to capture the meaning of human life and the ethical nature of actions. These are the two spheres on which I am going to focus.

First, the sphere of meaning constitutes the nucleus of what is most genuinely human, of what only the human being possesses. We are standing before the most fertile notion of contemporary thinking (phenomenology, hermeneutics, personalism, etc.), which we must continue to explore in more depth. Because of meaning, which is neither subjectivity, and its representations, nor actual reality, a common terrain opens up for human beings, a space for communication and for shared worlds. We humans live from meaning, because it allows us to share a common logos, which is at the base and precedes all manner of scientific and technological progress. The recovery of what is human has to pass through the stage of recovering meaning, something that we have "forgotten" and that we do not "remember", which is found precisely in a clouded human nature.

The concern for originating and for meaning was primordial in phenomenology and particularly in the last of Husserl's works: The Crisis of European Sciences and Transcendental Philosophy [99]. It studies the roots of the loss of ontology in modern science, from Galileo to present day, on the basis of the double reduction of physics to geometry and this to algebra. It attempted to reach exactitude, but in return, meaning was lost ([99], n. 2). Faced with this situation, Husserl proposes recovering the originating reality from which science derives, since the realities that science excludes are the biggest 
issues for humanity: questions that imply the meaning or the absence of the meaning of human existence ([99], n. 4). Mathematical idealities attempt to substitute the real world: the world that is truly perceptible to us. Husserl calls it "life-world" (Lebenswelt) ([99], n. 34a-b). Lebenswelt is the world of pre-scientific and extra-scientific life. It is the real world according to our intuition that we experience as beings of flesh and blood, for which all scientific idealization, all technical construction and all sociological structuring have a posterior and derived meaning ([99], n. 34c-d). Lebenswelt is the “originating world of meaning” ([99], n. 34d).

The crisis of the sciences (and humanity) comes from having broken the link with this Lebenswelt realm of originating evidence and, with it, the loss of having lost its own telos, its finality. This is because meaning is signification and reference, as well as intentionality towards an end. The therapy proposed by Husserl is not the return to an exclusively pre-scientific life or the escape to an extra-scientific life. His program consists of rediscovering the transcendentality of a Lebenswelt, which brings together all the worlds—scientific, economic, sociological ([99], n. 53-54)—and developing a life-world ontology ([99], n. 51). The difficulties this task poses are evident, but its inspiring premise is still valid: the problem does not lie in the scientific, economic or sociological structures, but rather in their lack of meaning, because of their disconnection from the living world.

Martin Heidegger also undertook a vigorous search for the roots, the original. In his Letter on Humanism, he specified that "ek-sistence” (a concept different from existence) consists of "dwelling proximally to being” ([47], p. 232). This led him to point out that genuine thinking must reach the level of ontology, conceived in terms of the search for the roots, the encounter with the original, which is at the same time the search for the permanent of what establishes the human residing ([47], p. 237). Working from the original significance of dwell as to stay or remain, Heidegger finds the origins of the present crisis in the loss of that habit, and consequently, he concludes that "first and foremost it is necessary to learn to dwell” ([47], p. 241). The search for the original (Ursprung) and permanent (bleiben), the understanding of true human dwelling, leads to capturing the meaning. Additionally, this is the object meditative thinking proposed by Heidegger: a thinking that is questioned by meaning [100].

The major danger for human dwelling lies in the false belief that man is the only player in unveiling what is real. This supreme danger, more so than all the wars, and destruction lie in technics, because it converts everything into calculable and manipulable; and this is precisely the essence of materialism: not that everything is material, but rather that all entity is simply work material. "Unveiling” thinking (bessinliche Denken) that looks for the meaning, as opposed to mere "calculating" thinking (rechnende Denken) only attentive to manipulation, offers a profound understanding, even of the meaning of technics itself. Because technics also unveils the phisis, given that man utilizes it to bring to light what was in fact hidden in its cells and fabrics [101]. Genuine thinking in Heidegger finally leads to dachten (remember) and to danken (give thanks). Man warns that existing means for him to be at one with the "sacred", with the "divine”. Only thus can man truly dwell on Earth, conjure up the danger of uprooting and find the path to authenticity (true self) [102].

Both Husserl and Heidegger find a powerful antecedent in Henri Bergson's proposal for the recovery of ontology. In La Pensée et le Mouvant, he records his opposition to those who attempt to marginalize man, in his daily existence, from the sphere of knowledge reserved exclusively for the sciences. Their concern for numbers and measurements renders them unable to answer themselves 
alone questions concerning meaning. From here, his statement that, "at least one part of our reality, our humanity, can be recovered in its original purity” [103].

In short, the construction of this new humanist story of "what is human" has to begin by re-proposing the centrality of meaning, which must be looked for in the reality itself, pre-scientific, of human nature and through meditative thinking. This is a thinking that wades through memory and that in the proximity of the sacred, reminding the human being of what it means to dwell in the world. This "dwelling in the proximity of the sacred" connects with another forgotten dimension of what is human: the "inalienable" essential constituent element dignity: the only transcendental foundation of human rights.

In effect, this meaning of the word "inalienable" has ever been linked to fundamental rights (the essential consequences of human dignity); however, the economicist mentality has downgraded and understood it in the weak sense of "inviolable" vis-à-vis others, but capable of being renounced by the subject himself. The "inalienable" was hinted at in the Roman conception of law when it referred to res extra-commercium, among which there was the inclusion of res communes and res sacrae. This intuition of the Roman mentality maintained a sense of limits to avoid chaos (hybris). The United States Declaration of Independence, Jefferson's doing, constitutes an extraordinary novelty in this respect, since the replacement of property by "the pursuit of happiness" allows us to understand the word "inalienable" in its powerful and rigorous sense. In effect, the renunciation of happiness seems much more anti-natural and absurd than the disposition of property. The admission of inalienable rights implies a conception of the person different from an isolated and self-sufficient monad and from the postmodernist conception of a "playful mask". It forces the understanding of the human person in agreement with its originating terminology as prosopon, as a being open to reality, as relationship with the origin, with others, with nature, with oneself ([3], p. 147). This idea of the connection between the inalienability and the grandeur of human beings means that the individual stops considering her/himself as pure unsatisfied desire, from the moment in which s/he opens up to others and experiences the fact that s/he is not sovereign, but rather the guardian and custodian of reality for her/his contemporaries and for the future generations.

To protect the "inalienable", we need to overcome the anthropological dualism between res extensa and res cogitans: the opposition between the individual will as a subject and the rest of reality reduced to a mere object capable of being manipulated at the mercy of that will and, therefore, entirely alienable. The body is not a tool or just another commodity that can be disposed of; it is not something that I have, but rather something that I am, as Gabriel Marcel, among others, conscientiously pointed out throughout his work [104]. The human body is not a thing. The individual does not possess his or her own body as an alienable, relinquishable and divisible good susceptible to becoming the object of commercial transactions (the sale of sperm, ovules, organs, etc.). From this, it follows that we cannot speak of "rights over my own body" in the sense of free disposition, but rather as a right duty to its diligent and responsible use and care.

The road towards the ontological recovery of what is human, as we have seen, also touches on rediscovering the ethical dimension of human actions. In this aspect, the rehabilitating thinking of practical philosophy, inspired by Aristotle, has offered valuable suggestions. Robert Spaemann ([84], pp. 89-112), welcoming the distinction made by Alisdair MacIntyre [105], proposes removing reasoning from the certainty paradigm, into which Descartes introduced it and which has proved unable 
to confront the enormous complexity of the real, and re-introduce it into the truth paradigm. According to the certainty model, access to reality depends exclusively on the adequate method that guarantees objectivity. However, rationalization at all costs, typical of this model, has brought with it the greatest explosion of irrationality known to date. Additionally, the supposed humanizing transformation of the world has brought us an unprecedented height of dehumanization. According to the truth model, the radical and genuine is not objectivity, but rather reality. Additionally, we cannot automatically access the foundation of reality by the mere application of a rational method. Such access requires a laborious apprenticeship, which is fed from a long tradition of thinking. There is no science without history, education, research communities or ethical and political components: a science separate from these is a fiction. Our ways of knowing owe much to know-how or craftsmanship than pure speculation, exempt from historical and ethical connotations and motivations. The methodological ideal of the certainty paradigm implies univocal rationality, while the truth paradigm means an open and analogical use of reasoning. The first model attempts to offer security at the cost of reductionism; the second assumes uncertainty and contrasting hypotheses until hitting on the one that best fits reality, assuming vulnerability and the possibility of error, but giving priority to advances in the knowledge of reality in contrast to the obsessive justification of a thesis ([84], pp. 119-22).

This concerns substituting an epistemological paradigm (such as a basic model for the theory of truth) for an anthropological paradigm that is neither psychologist nor relativist. The difficulties run deep, because we are dealing with conceiving the truth as perfection of the person, and this proves incompatible with rationalism and subjectivism. Consequently, the recovery of ontology, as suggested by Alejandro Llano [106], implies re-establishing the original connection between truth and virtue; that is, between truth and perfecting the person. The idea of virtue is of central importance in the recovery of what is human, but it only makes sense from a perspective of practical reasoning, which overcomes the subject-object dialectic consecrated by rationalist ethics. For the terminal rationalism of our times, reality is pure facticity, a collection of external and demonstrable facts; while subjectivity is and empty and self-referential capsule. Reality is divided into two isolated worlds. In the first, we have rational calculation (rational choice): in the field of scientific, determinist and neutrally assessed evidence. The subjective, in contrast, would be the field of the irrational, where there is no place for the universal, because it is governed by the preferences, desires and feelings of each individual. This is the realm of moral emotion and spontaneity, which validates all of the options. In a panorama of this kind, the concept of "virtue" is completely bereft of meaning if we understand it as growing in being when the person, in their actions, "follow the truth". Virtue is gaining freedom, which is obtained when the person orients his/her life towards truth. It is an anthropological gain, that is, a gain in the perfecting of the person, which is realized through acquiring habits. This concept of virtue is drifting today in the midst of great mistakes, but its recovery (as MacIntyre has pointed out ([105], pp. 204-44)) is of vital importance.

From the perspective of virtue, human beings see themselves as being able to grow cognitively and ethically, which remains a stable part of their person in the form of habits. It follows that the increase of cognitive and practical habits is only one way to grow in perfection and, with it, grow in freedom. Cognitive and practical habits are those that allow a person to "take charge" of the profundity of their human condition and their own historical situation [107]. The perspective of habits is that which allows for really overcoming the objectivity-subjectivity dialectic, because it appeals to an increase of the 
perceptive capabilities in the person, and this is manifest in the anthropological meaning that experience acquires in this context. In effect, scientific objectivism appeals to the "experiment", to the empirical verification of the fact. In contrast, the habit perspective (practical reasoning) refers to "experience", in the humanist sense, which is knowledge that deals with the context and the surroundings ([84], pp. 35-36). It is the sense in which we commonly speak of an "experienced person": not someone who accumulates theoretical knowledge or who shuts themselves within subjectivity, but rather who knows how to maintain within themselves the trace of their vital contact with the world and people, in such a way that they have learned to behave more appropriately and wisely. We are therefore talking of a knowing of things and of a knowing oneself: appropriating the real, respecting their own being ([107], pp. 137-38).

The central role of virtue in the humanist recovery of "what is human" is directly linked to the ethical thinking of Aristotle's. This is a thinking that underlines, at least, three fundamental elements of human actions. Firstly is the importance of the dimension of praxis, as distinct from poiesis (and this difference shows the way to overcome economicism and modern productivism). Secondly is the re-evaluation of the dimension of ethos, of experience, which leads to distinguishing the ethical truths as opposed to simply theoretical truths (this leads to overcoming ethical rationalism, which overlooks experience). Thirdly is the noteworthy role played by phronesis (prudence) as a fundamental factor in the formation of ethics (which leads to overcoming ethical emotivism and the division between reasoning and sentiments).

Aristotle tackles the difference between praxis and poiesis from the very first lines of Nicomachean Ethics ([18], Book I, No. 1). The starting point is the intentional nature of all human actions. However, he sets out one clear difference in the end, as some are the same actions (praxis) and others are certain works (poiesis). In effect, poiesis is the sphere of what in Rome was called facere: the type of activity carried out exclusively with an eye toward achieving a result, of a given thing that one attempts to give rise to; therefore, "the end of production (poiesis) is distinct from production itself". This means that "production (poiesis) is not an end in the absolute sense, but only something which is relative with regard to the creation of a given thing” ([18], Book VI, No. 5).

Praxis, on the other hand, refers to what was later called agere, that is, those actions that are realized for their own ends, that are none other than good practice (eupraxis) ([18], Book VI, No. 2). "In action what one does is an end (in the absolute sense), so a virtuous life is an end and the object of desire is this end" ([18], Book VI, No. 5). However, the importance of the distinction lies in the more elevated character of praxis over poiesis, to the degree of stating in Politics ([17], Book VIII, 1325 b, 28), that the activity of divinity can be considered praxis, but never poiesis.

In effect, the primacy of praxis is what guarantees the superiority of the personal over the world of objects and, in this sense, is a way of overcoming the thinking of modernity, which gives primacy to technics and production, even for writers, such as Marx, who reclaim the notion of praxis, but, as Hanna Arendt reminds us, having lost its original sense and reduced to the concept of labor, which brings in its wake the reduction of man to animal laborans [108]. In the task of recovering what is human, it is important to avoid confusion between work and employment, which is the outcome of the predominance of instrumental reasoning. Hanna Arendt criticizes the exaltation of work as a central human activity, because of the risk of giving primacy, in economicist terms, to productive and lucrative tasks. However, she offers no alternative to her distinction between labor, action (praxis) and work in 
its technical or artistic dimension ([108], pp. 161-63). In my view, it would be more correct to state that there is no true human work without the praxical dimension or ethics. Human action is multidimensional and not only produces functional effects, but above all, it has to produce perfecting effects. The same subject can be a lawyer or an engineer and also the father of a family or a writer of short stories. The importance of reflecting on the fact that work is something more than employment lies in passing from one plane that is purely objective and functional to a dimension that is subjective and personal. Additionally, from this, it follows that the full sense of human work cannot be conceived from an anthropology impoverished by economicist pragmatism. The fundamental value of work is the anthropological perfecting, intellectual and ethical gain that is earned and extended through work (praxis). When this aspect is systematically marginalized, this causes an absence of theoretical tension and ethical enthusiasm, and then, creativity diminishes, while conformity increases: everything tends to come to a halt. This is the most renowned pathology found in consumer societies ([108], pp. 137-39). It follows that overcoming economicism lies in the line of an anthropological interpretation (not instrumental) of work. The added value of work is, foremost, gaining human perfection above and beyond economic performance (although this is advisable). It follows that in the task of recovering the human, the social recognition of the humanist value (ethical and sapiential) of work is fundamental; this has been considerably obscured with its merchandization. From this point of view, what is decisive for progress in productivity is not money, but rather an increase of theoretical and practical habits. For there to be more work, we have to work better, and in order to work better, we have to think better and make better decisions. This is not incompatible with technology; quite the opposite: the connection between technology and humanism is the major challenge today: to establish a proper relationship between ethics and technics that would guarantee the true perfecting of the individual ([106], pp. 137-38).

In this same sense of the primacy of praxis, one has to understand that ethics does not belong to the sphere of "logos apophantikòs", which concerns things that are necessary (such as geometry, algebra or metaphysics), but rather, ethics belongs to the sphere of "ortos logos”, to right reasoning, which deals with the contingent, about what can be another way ([18], Book II, No. 9 and Book VI, No. 4). Aristotle's right reason implies the possibility to humanly reach perfection, since this means a permanent rectification of intention to accommodate desire and the search for good in each case. For this reason, practical truth, as opposed to theoretical truth, is never totally true, because it always allows for "even better". All of this implies that in ethical life, it is impossible to theoretically know principles independently of their practical application. In other words, the ethical model can only be personified el hombre esforzado (Spoudaios), he who has brought up to date to the maximum all of the powers and has interiorized the habit of ethical and dianoetic virtues ([18], Book II, No. 1). It also follows from here that in Aristotelian thinking, prudence (phronesis) takes on a fundamental importance, which involves the link between ends and means, between rationality and emotivity, thus overcoming rationalism and logical empiricism. Of course, reasoning has an important place in ethics, but this is not the same type of reasoning that operates in purely theoretical matters (that which cannot be otherwise), but rather practical reasoning, which has to take into account the circumstances ([18], Book II, No. 1) and which requires dialogue and argumentation, not demonstration, as already pointed out by S. Toulmin [109] and Ch. Perelman [110].

Additionally, a final consideration: When we seem to be heading for a post-literary culture, the need proves even more pressing to rediscover the fruits of reflecting on the original and genuinely human 
content in classic, ancient and more recent texts. It is in these that we find set out the figure of the homo civilis, the good man, the good citizen, who knows how to keep himself from the excesses of the homo oeconomicus and the corruption of the "zoon politikon". On the basis of this literary wisdom, I propose the rehabilitation of the homo humanus, who undertakes the greatness and profundity of his humanitas.

\section{Conflicts of Interest}

The author declares no conflict of interest.

\section{References and Notes}

1. Michel Foucault. Les mots et les choses. Une Archéologie des Sciences Humaines. Paris: Gallimard, 1966, p. 39.

2. Gianni Vattimo. La fine della Modernità. Torino: Einaudi, 1985, p. 23.

3. Jesús Ballesteros. Postmodernidad: Decadencia o Resistencia. Madrid: Tecnos, 1989, pp. 17-24.

4. Erwin Panofsky. Meaning in the Visual Arts. Garden City: Doubleday, 1955, Chapter V.

5. Erwin Panofsky. Renaissance and Renascences in Western Art. Stockholm: Almqvist \& Wiksell, 1960, p. 190.

6. Lewis Mumford. Technics. and Civilization. New York: Harcourt Brace and Co., 1934, p. 179.

7. José Ortega y Gasset. “Sobre el punto de vista en las artes.” In Obras completas. Madrid: Revista de Occidente, 1946-1979, p. 443 (translation mine). M. Heidegger expresses himself in a similar way as Ortega in his important essay "The Age of World Picture": "To be modern means to see the world as an image, which is the same as the apparition of individual as a subjectum within what exists"; and "to be a subjectum means to be able to objectivize, that is to objectively visualize, to quantify with exactness, to calculate, since the modern freedom of subjectivity is wholly resolved in the objectivity which is inherent to it" (Martin Heidegger. "The Age of World Picture”. In The Question Concerning Technology and Other Essays. Translated by William Lovitt. New York: Harper and Row, 1977, pp. 115-54).

8. José A. Maravall. Velázquez y la Modernidad. Madrid: Alianza Editorial, 1987.

9. Arnold Hauser. The Sociology of Art. Chicago: University of Chicago Press, 1982.

10. Leonardo Da Vinci. Aforismos, 4th ed. Spanish translation by Ernesto García. Madrid: EspasaCalpe, 1965, see aphorisms: 34-37 and 314-450.

11. Paul Oskar Kristeller. Renaissance Thought and Its Sources. New York: Columbia University Press, 1979.

12. Max Weber. Science as a Vocation (delivered as a speech at Munich University, 1918). Munich: Duncker \& Humblodt, 1919.

13. Galileo Galilei. Il Saggiatore (1623). Spanish translation by José María Revuelta. Madrid: Aguilar, 1981, p. 197.

14. Alexander Koyré. “Le monde de 'l'a-peu-pres' a l'univers de la précision.” In Etudes d'histoire de la pensée philosophique. Paris: Gallimard, 1971, pp. 191-228.

15. René Descartes. "Meditations de prima philosophia, VI.” In Oeuvres Philosophiques. Paris: Garnier, 1973, vol. II, p. 177 and following. 
16. This mode of thinking by way of disjunctives leads to the insipid questions found in public opinion polls which necessarily lead those who believe in complementariness to appear as people who "do not know/have no answer".

17. Aristotle. "Politics. Book 1" In Aristotle in 23 Volumes. Translated by Horace Rackham. Cambridge: Harvard University Press, London, William Heinemann Ltd., 1944, vol. 21, section 1256a-1257b.

18. Aristotle. "Nichomachean Ethics.” In Aristotle in 23 Volumes. Translated by Horace Rackham. Cambridge: Harvard University Press, London, William Heinemann Ltd., 1944, vol. 19, section 1133a-1134a.

19. Karl Polanyi. The Great Transformation. New York: Holt, 1944.

20. Jacques Pirenne. Histoire Economique et Sociale du Moyen Age. Paris: PUF, 1933.

21. Albert Otto Hirschman. The Passions and the Interests: Political Arguments for Capitalism before Its Triumph. Princeton: Princeton University Press, 1977.

22. Thomas Hobbes, Leviathan, cap. XIII, 9. In Hobbes's Leviathan: Reprinted from the Edition of 1651. Edited by William George Pogson. Oxford: Clarendon Press, 1929, p. 96.

23. Robert Spaemann. Zur Kritik der Politischen Utopie. Zehn Kapitel Politischer Philosophie. Stuttgart: Klett-Cotta, 1987, p. 190.

24. Bernard Mandeville. The Fable of the Bees: Or Private Vices, Public Benefits (1714). Irwing Primer edition. New York: Capricorn Books, 1969.

25. Adam Smith. “The Division of Labour.” In An Inquiry into the Nature and Causes of the Wealth of Nations. Edwin Cannan edition. Chicago: University of Chicago Press, 1976, Book I, Chapter 2, vol. 2a, p. 456.

26. Benjamin Franklin. Autobiography and Other Writings (1771). Edited by Russell Nye. Cambridge: Riverside, 1958, p. 269.

27. Horace. "Epistle to Lucilius.” In Horace, Satires and Epistles; Persius Satires. Edited by Niall Rudd. London: Penguin, 2005, pp. 68-79.

28. Max Weber. The Protestant Ethic and the Spirit of Capitalism and Other Writings. Translated by Peter Baehr and George Wells. London: Penguin 2002, pp. 9-12 and 15-16.

29. Anselm Dietz. Der Homo oeconomicus. Hamburg: Gütersloh, 2005, pp. 54-63.

30. William Petty. Political Arithmetic. In The Economic Writings of Sir William Petty. London: Routledge/Thoemmes Press, 1997, vol. 1, pp. 233-313.

31. Ernest Becker. The Fight against the Bad. New York: Free Press, 1973, p. 143.

32. Alfred Suchanek. "Homo oeconomicus.” In Lexikon der Wirtschaftsethik. Edited by G. Enderle Friburg: Herder, 1993, pp. 426-31. See also: Marco Mansdörfer. Zur Theorie des Wirtschaftsstrafrechts. Hamburg: C.F. Muller, 2011, pp. 20-32.

33. Jeremy Bentham. An Introduction to the Principles of Morals and Legislation (1789). London: T. Payne and Sons, 1981, vol. 1, Chapter I.

34. Gary Becker. The Economic Approach to Human Behavior. Chicago: University of Chicago Press, 1976, pp. 123-38. See also: A Treatise on the Family. Cambridge: Harvard University Press, 1991, pp. 159-66.

35. E. Fritz Shumacher. Small Is Beautiful. Economics as if People Mattered (1973). New York: Harper-Perennial, 2010, p. 125. 
36. Gilbert K. Chesterton. The Return of Don Quijote (1926). Cornwall (UK): House of Stratus, 2008, p. 38

37. Henri Saint-Simon. “L’Organisateur.” In Oeuvres Complètes. Paris: Anthropos, 1966, vol. 2, pp. 1002-12.

38. Lewis Mumford. The Myth of the Machine. NewYork: Harcourt Brace Jovanovich, 1967, Volume I. Spanish edition: El mito de la máquina. Translated by Diego Núñez. Buenos Aires: EMECE, 1969, p. 419.

39. Alvin Toffler. The Third Wave. New York: Bantam Books, 1980, p. 46.

40. Charles Péguy. “De Jean Coste.” In Oeuvres en Prose. Paris: Gallimard, 1987, vol. I, p. 1018 and following.

41. E. Fritz Shumacher. A Guide for the Perplexed. New York: Harper-Perennial, 1978.

42. Alejandro Llano. Humanismo Cívico. Barcelona: Ariel, 1999, p. 145.

43. Arnold Gelhen. Anthropologie et psychologie sociale. Paris: PUF, 1990, pp. 311-28.

44. Jean François Lyotard. La Condition postmoderne: Rapport sur le savoir. Paris: Éditions de Minuit, 1979, p. 12.

45. Abrecht Wellmer. The Persistence of Modernity. Essays on Aesthetics, Politics and Postmodernism. Translated by Dennis Midgey. Cambridge: Polity Press, 1991, p. 231.

46. Alain Touraine. Critique of Modernity. Oxford: Blackwel, 1995, pp. 21-24.

47. Martin Heidegger. “Letter on Humanism.” In Basic Writings: Martin Heidegger (1947). London: Routledge, 1977, pp. 215-59.

48. Gianni Vattimo. Oltre l'interpretazione. Roma-Bari: Laterza, 1994, pp. 146-47.

49. Gianni Vattimo. Il soggetto e la maschera. Milano: Bompiani, 1974, p. 296.

50. Gilbert Hottois. Essais de philosophie bioéthique et biopolitique. París: Vrin, 1999, p. 68.

51. Peter Sloterdijk. Regeln fur den Menschenpark. Frankfurt am Main: Suhrkamp, 1999. In September 1999, Peter Sloterdijk delivered a speech to a circle of intellectuals at Schloss Elmau in Bavaria that was to give the attending media an incentive to inaugurate a heated debate over the accuracy of his observations and especially over whether he advocates harnessing genetic technology to the improvement of human kind. Under the motto Rules for the Human Park. A Response to the Letter on Humanism, the speech was subsequently published in a book form with like title. (Spanish translation: Normas sobre el Parque Humano. Madrid: Siruela, 2003).

52. Peter Sloterdijk. “Vivre chaud et penser froid.” In Multitudes, $n^{\circ}$ III (2000): 21-22.

53. Hervé Kempf. La Révolution Biolithique. Humains artificiels et machines animées. Paris: Albin Michel, 1998.

54. Tristam Engelhardt. The Foundations of Bioethics. Oxford: Oxford University Press, 1997, p. 68.

55. Richard Rorty. Philosophy and the Mirror of the Nature. Princeton: Princeton University Press, 1979.

56. Gilbert Hottois. La science entre valeurs modernes et postmodernité. Paris: Vrin, 2005.

57. Roland Barthes. The Pleasure of the Text. New York: Hill and Wang, 1975.

58. Michel Foucault. Nietzsche, Freud, Marx. Paris: Minuit, 1965.

59. The critic and translator Barbara Johnson has emphasized Mallarmé's influence on twentieth-century French criticism and theory: "It was largely by learning the lesson of Mallarmé that critics like Roland Barthes came to speak of 'the death of the author' in the making of literature. Rather than 
seeing the text as the emanation of an individual author's intentions, structuralists and de-constructors followed the paths and patterns of the linguistic signifier, paying new attention to syntax, spacing, intertextuality, sound, semantics, etymology, and even individual letters. Theoretical styles of Jaques Derrida, Julia Kristeva, Maurice Blanchot, and especially Jaques Lacan also owe a great deal to Mallarmé’s critical poem” (Barbara Johnson. 'Translator's Note' to Stéphane Mallarmé.” In Divagations. Translated by Barbara Johnson. Cambridge: Harvard University Press, 2007, p. 301).

60. Jaques Derrida. Dissemination. Translated by Barbara Johnson. Chicago: University of Chicago Press, 1981, p. 315.

61. Frederik Niestzche. The Case of Wagner, Nietzsche Contra Wagner, and Selected Aphorisms. Translated by Anthony Ludovici. Edimburg-London: Foulis, 1911 (free online 2007), n. 6.

62. Frederik Niestzche. Beyond Good and Evil. Translated by Judith Norman and edited by RolfPeter Horstmann. Cambridge: Cambridge University Press, 2002, annotation number 254.

63. Frederik Niestzche. "The song of the nightwalker”. In Thus Spoke Zarathustra. Translated by Adrian Del Caro; Edited by Robert Pippin. Cambridge: Cambridge University Press, 2006.

64. "What is philosophy for him except a sort of philology without end that is forever developing, a philology that shall never be pinned down? And if interpretation can never end, this simply means that there is nothing to interpret. There is nothing absolutely primary since deep down everything is interpretation. Each sign is in itself the interpretation of other signs, and not the thing being offered to interpretation” (Michel Focault. “Nietzsche, la généalogie, l’histoire.” In Hommage à Jean Hyppolite. París: PUF, 1971, pp. 145-72).

65. François Lyotard. The Postmodern Explained: Correspondence 1982-1985. Translated by Don Barry. Edited by Julian Pefanis and Morgan Thomas. Minnesota: University of Minnesota Press, 1993.

66. Gilles Deleuze, and Félix Guattari. Anti-Oedipus. Translated by Robert Hurley, Mark Seem and Hellen R. Lane. London and New York: Continuum, 2004, vol. 1 of Capitalism and Schizophrenia.

67. Commentators have almost unanimously insisted upon the continuity we are presenting between modernism and post-structuralism. The most lucid of all these commentators is probably Andreas Huyssen. After the Great Divide: Modernism, Mass Culture, Postmodernism. Indiana: Indiana University Press, 1986.

68. Frederik Niestzche. Unfashionable Observations. Translated by Richard T. Grey. Stanford: Stanford University Presss, 1995, part III, n. 6.

69. Frederik Niestzche. The Dawn of Day. Thoughts on the Prejudices of Morality. Translated by John Macfarland Kennedy. New York: Mc Millan Co., 1911.

70. François Lyotard. The Postmodern Condition: A Report on Knowledge. Translated by Geoff Bennington and Brian Massumi. Minnesota: University of Minnesota Press, 1984. Hume, in the book quoted, expresses the same idea: “human's life is of no more importance for the universe than the life of an oyster" (p. 119).

71. Frederik Jameson. Postmodernism. The cultural Logic of Late Capitalism. Durham: Duke University Press, 1991, pp. 79-87. 
72. Frederik Niestzche. Human, All Too Human: A Book for Free Spirits. Translated by Reginald John Hollingdale. Cambridge: Cambridge University Press, 1996, annotation number 72.

73. Robert Musil. Essays. Paris: Seuil, 1984, p. 170.

74. Max Horkheimer. “Traditional and critical theory.” In Critical Sociology: Selected Readings. Edited by Paul Connerton. Harmondsworth: Penguin, 1976.

75. Herbert Marcuse. One-Dimensional Man: Studies in Ideology of Advanced Industrial Society (1964). London: Routledge, 1991.

76. Max Horkheimer, and Theodor Adorno. Dialectic of Enlightenment. Translated by Edmund Jephcott. Stanford: Stanford UP, 2002.

77. Theodor Adorno. Minima Moralia. Reflection from Damaged Life. London: Radical Thinkers, 1981. See also: David Held. Introduction to critical theory: Horkheimer to Habermas. Berkeley: University of California Press, 1980.

78. Jürgen Habermas. The Theory of Communicative Action (1981). Translated by Thomas McCarthy. Boston: Beacon, 1984. See also: Raymond Geus. The Idea of a Critical Theory: Habermas. and the Frankfurt School. Cambridge: Cambridge University Press, 1981.

79. Jürgen Habermas. The Philosophical Discourse of Modernity (1985). Translated by Frederick Lawrence. Cambridge: MIT Press, 1987, pp. 81-89. See also: “Technology and Science as Ideology.” In Toward a Rational Society. Student Protest, Science, and Politics. Tanslated by Jeremy J. Saphiro. Boston: Beacon Press, 1971, pp. 119-21.

80. Jürgen Habermas. Between Facts and Norms (1992). Cambridge: MIT Press, 1998.

81. Axel Honneth. The Critique of Power: Reflective Stages in a Critical Social Theory (Studies in Contemporary German Social Thought). Cambridge: MIT Press, 1991.

82. Jürgen Habermas. The Postnational Constellation. Political Essays (1998). Translated by Max Pensky. Cambridge: MIT Press, 2001, pp. 95-96.

83. Jürgen Habermas. Legitimationsprobleme im Spätkapitalismus. Frankfurt am Main: Surkham, 1973. Spanish edition: Problemas de Legitimacion del Capitalismo Tardío. Translated by Juan Echeverry. Madrid: Cátedra, 1999, pp. 67-80.

84. Robert Spaemann. Essays in Anthropology: Variations on a Theme (1987). Translated by Guido De Graaff and James Mumford. Oregon: Cascade Books, 2010.

85. Francis Fukuyama. America at the Crossroads: Democracy, Power and the Neoconservative Legacy. New Haven: Yale University Press, 2006, pp. 21-24.

86. Leo Strauss. “The Crisis of Our Time.” In The Predicament of Modern Politics. Edited by Howard Spaeth. Detroit: University of Detroit Press, 1964, pp. 41-54.

87. Leo Strauss. On Tyranny. New York: Free Press, 1991, pp. 22-23.

88. Leo Strauss. "What Is Political Philosophy?” In Leo Strauss, What Is Political Philosophy? and Other Studies. Glencoe: The Free Press, 1959, pp. 18-19.

89. Leo Strauss. The City and Man. Chicago: Rand McNally, 1964, pp. 10-17.

90. Robert Kagan, and William Kristol. Present Dangers: Crisis and Opportunity in American Foreign and Defense Policy. San Francisco: Encounter Books, 2000, pp. 3-25.

91. William Bennett. "Morality, Character and American Foreign Policy." In Robert Kagan and William Kristol. Present Dangers: Crisis and Opportunity in American Foreign and Defense Policy. San Francisco: Encounter Books, 2000, pp. 289-307. 
92. Frederik Hayek. The Road to Serfdom. Chicago: University of Chicago Press, 1944.

93. Murray Friedman. The Neoconservative Revolution Jewish Intellectuals and the Shaping of Public Policy. Cambridge: Cambridge University Press, 2005, p. 44.

94. Zeev Sternhell. The Anti-Enlightenment Tradition. New Haven: Yale University Press, 2010.

95. Peter Berger, and Thomas Luckmann. The Social Construction of Reality: A Treatise in the Sociology of Knowledge. New York: Anchor Books, 1966.

96. Michael Novak. The Spirit of Democratic Capitalism. New York: Simon and Shuster, 1982.

97. Richard J. Neuhaus. Naked Public Square. Religion and Democracy in America. Michigan: Eerdmans, 1986.

98. James Hillman. The Force of Character. New York: Random House, 1999, p. 395.

99. Edmund Husserl. The Crisis of European Sciences and Transcendental Philosophy (1936). Translated by David Carr. Evanston: Northwestern University Press, 1970.

100. Martin Heidegger. Sein und Zeit. Tubingen: Niemeyer, 1927, pp. 42-51, 117-26. English version: Being and Time. Translated by Joan Stambaugh. Albany: State University of New York Press, 1996.

101. Martin Heidegger. “The Question Concerning Technology.” In Martin Heidegger. Basic Writings, 2nd ed. Edited by David Farrell Krell. New York: Harper Collins, 1993.

102. Walter Richardson. Heidegger, Trough Phenomenology to Thought. La Haya: Martinus Nijhoff, 1963, pp. 15-18.

103. Henry Bergson. La pensée et le mouvant. París: Seuil, 1969, pp. 27-74.

104. Gabriel Marcel. Etre et Avoir. París: Aubier, 1935.

105. Alisdair MacIntyre. After Virtue. Indiana: Notre Dame University Press, 1981, pp. 51-79.

106. Alejandro Llano. Humanismo Cívico. Barcelona: Ariel, 1999, pp. 146-47.

107. Alejandro Llano. La Nueva Sensibilidad. Madrid: Espasa, 1988, p. 133.

108. Hannah Arendt. The Human Condition. Chicago: University Press, 1958, pp. 111-82.

109. Stephen Toulmin. An Examination of the Place of Reason in Ethics. Cambridge: Cambridge University Press, 1950, pp. 137-42.

110. Chaim Perelman. Justice et Raison. Paris: PUF, 1963, pp. 68-77.

(C) 2014 by the author; licensee MDPI, Basel, Switzerland. This article is an open access article distributed under the terms and conditions of the Creative Commons Attribution license (http://creativecommons.org/licenses/by/3.0/). 